\title{
Comparative Study of Supervised Machine Learning Algorithms for Predicting the Compressive Strength of Concrete at High Temperature
}

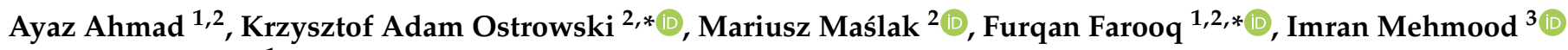 \\ and Afnan Nafees ${ }^{1}$ \\ 1 Department of Civil Engineering, Abbottabad Campus, COMSATS University Islamabad, \\ Abbottabad 22060, Pakistan; ayazahmad@cuiatd.edu.pk (A.A.); afnan@cuiatd.edu.pk (A.N.) \\ 2 Faculty of Civil Engineering, Cracow University of Technology, 24 Warszawska Str., 31-155 Cracow, Poland; \\ mmaslak@pk.edu.pl \\ 3 Department of Building and Real Estate, The Hong Kong Polytechnic University, Hung Hom, Kowloon, \\ Hong Kong, China; Imran.mehmood@connect.polyu.hk \\ * Correspondence: krzysztof.ostrowski.1@pk.edu.pl (K.A.O.); furqan@cuiatd.edu.pk (F.F.)
}

check for updates

Citation: Ahmad, A.; Ostrowski, K.A.; Maślak, M.; Farooq, F.;

Mehmood, I.; Nafees, A. Comparative Study of Supervised Machine

Learning Algorithms for Predicting the Compressive Strength of Concrete at High Temperature. Materials 2021, 14, 4222. https://doi.org/10.3390/ ma14154222

Academic Editor: Enrique Casarejos

Received: 5 July 2021

Accepted: 23 July 2021

Published: 28 July 2021

Publisher's Note: MDPI stays neutral with regard to jurisdictional claims in published maps and institutional affiliations.

Copyright: (c) 2021 by the authors. Licensee MDPI, Basel, Switzerland. This article is an open access article distributed under the terms and conditions of the Creative Commons Attribution (CC BY) license (https:/ / creativecommons.org/licenses/by/ $4.0 /)$.

\begin{abstract}
High temperature severely affects the nature of the ingredients used to produce concrete, which in turn reduces the strength properties of the concrete. It is a difficult and time-consuming task to achieve the desired compressive strength of concrete. However, the application of supervised machine learning (ML) approaches makes it possible to initially predict the targeted result with high accuracy. This study presents the use of a decision tree (DT), an artificial neural network (ANN), bagging, and gradient boosting (GB) to forecast the compressive strength of concrete at high temperatures on the basis of 207 data points. Python coding in Anaconda navigator software was used to run the selected models. The software requires information regarding both the input variables and the output parameter. A total of nine input parameters (water, cement, coarse aggregate, fine aggregate, fly ash, superplasticizers, silica fume, nano silica, and temperature) were incorporated as the input, while one variable (compressive strength) was selected as the output. The performance of the employed ML algorithms was evaluated with regards to statistical indicators, including the coefficient correlation $\left(\mathrm{R}^{2}\right)$, mean absolute error (MAE), mean square error (MSE), and root mean square error (RMSE). Individual models using DT and ANN gave $\mathrm{R}^{2}$ equal to 0.83 and 0.82 , respectively, while the use of the ensemble algorithm and gradient boosting gave $\mathrm{R}^{2}$ of 0.90 and 0.88 , respectively. This indicates a strong correlation between the actual and predicted outcomes. The k-fold cross-validation, coefficient correlation $\left(\mathrm{R}^{2}\right)$, and lesser errors (MAE, MSE, and RMSE) showed better performance than the ensemble algorithms. Sensitivity analyses were also conducted in order to check the contribution of each input variable. It has been shown that the use of the ensemble machine learning algorithm would enhance the performance level of the model.
\end{abstract}

Keywords: concrete; compressive strength; high temperature; prediction; decision tree; bagging; gradient boosting

\section{Introduction}

Due to the fact that concrete has a relatively low cost when compared to other materials, as well as the fact that it is commonly used in engineering structures all over the world, its technology is subjected to constant innovations and improvements [1]. The fast and advanced development of urbanization requires a high demand for concrete [2], which possesses many desired properties including compressive strength, the ability to adopt any shape, and the capacity to resist environmental conditions [3]. In addition, porosity, impact resistance, fire resistance, durability, and acoustic insulation are also cited as being the advantages of concrete [4]. These various aspects enable it to be applied in the construction 
of infrastructures, dams, tunnels, bridges, and reservoirs [5]. The local availability of ingredients, such as coarse aggregate, fine aggregate, water, and binding material, significantly influences the economical factor [6]. In comparison, other building materials such as steel also possess many properties but cannot be cheaper than concrete. However, in order to make concrete a more advantageous material with improved properties, the techniques of adding other materials such as fly ash, silica fume, other cementitious material, and various fibers are widely adopted [7-9]. The use of waste materials in concrete plays a vital role in minimizing environmental risks, as well as in reducing the cost of the material [10]. High temperature and fire severely affect the properties of concrete in both its fresh and hardened states [11]. Some structures or structural elements are exposed to high temperatures, i.e., chimneys, factories with chemicals, and structures used in atomic industries. Moreover, the casting and curing of concrete in hot areas are considered a challenging task to perform, and what is more, concrete loses its mechanical properties (compressive and flexural strength) at high temperature, which ultimately results in the loss of its durability [12].

The development of new materials and methods for protecting against high temperatures has gained more importance in the field of research due to the increased number of incidents caused by fire $[13,14]$. The effect of fire is considered as a high frequency disaster, which not only causes the deterioration of cement composites, but also plays a role in the spalling of such material $[15,16]$. The paper [17] indicated that the resistance of a structure against the impact of high temperature caused by fire is one of the critical factors that influence the safety of using structures. This issue requires further research. Concrete is a commonly applied material and is also considered to be one of the best materials for protecting against high temperatures and the effect of fire $[18,19]$. The components of concrete (at the stage of the hydration of $\mathrm{C}-\mathrm{S}-\mathrm{H}$ and $\mathrm{Ca}(\mathrm{OH})_{2}$, and at the stage of the formation of calcium aluminate gels), due to an extended exposure to heat, can disintegrate. This can result in the deterioration of the physicochemical properties of concrete. Therefore, scientists concentrate on analyzing the influence of raised temperature on the mechanical properties of hardened concrete. The differences in the flexural and compressive strength of both ordinary and high-performance concrete have also been investigated when cooled in various conditions (air and water) [20]. In cement composite material (concrete), the decomposition reaction occurs due to the high porosity of the cement matrix and a decrease in strength parameters. The residues of calcium hydro silicate can be recognized in the cement matrix when the material is exposed to high temperatures of about 600 to $700{ }^{\circ} \mathrm{C}$ [21]. The performance of other types of concrete, i.e., lightweight concrete, have also been investigated with regards to the impact of high temperature [22]. Extensive research work has been carried out by researchers in order to investigate the mechanical properties of concrete heated to temperatures of up to $800^{\circ} \mathrm{C}$ [23-25] or higher [26-28]. It was proven that the rise in the natural temperature (which depends on the climate zone) also has a significant effect on the properties of concrete, which also involves several energy projects $[29,30]$.

Although concrete is generally a non-combustible material, its chemical, physical, and mechanical properties are directly affected by excessive temperature [31]. Thermal stresses, decomposition, and dehydration cause the spillage, perforation, and cracking of concrete [32]. Moreover, the strength properties of the ingredients of concrete at high temperatures are reduced. Cement paste requires a standard temperature range in order to work effectively inside the concrete matrix. High temperature does not allow cement paste to contribute positively towards the strength of concrete. This is especially the case for highstrength concrete, as it requires a normal temperature to achieve its desired strength [33]. The failure of concrete due to fire is caused by many factors, such as the heating rate and temperature, or structural element conditions, i.e., the application of loads [34]. Therefore, it is usually difficult to analyze the direct effect of high temperature on concrete, especially with regards to the microstructural changes of the aggregate, hydrated cement paste, and interfacial transition zone [35]. 
Sammy et al. [36] studied the compressive strength and properties of high-performance concrete at high temperatures of about 800 and $1100^{\circ} \mathrm{C}$, as well as during cooling. They investigated that the strength properties decreased sharply after a gradual (26-34\%) and rapid cooling process (22-28\%). Haruin at al. [37] investigated the effect of high temperature on the compressive strength and splitting tensile strength of light weight concrete with fly ash. The experimental investigation was conducted at 200,400 , and $800{ }^{\circ} \mathrm{C}$. In the case of $800{ }^{\circ} \mathrm{C}$, a decrease by $63.8 \%$ and $76.45 \%$ in the compressive strength and the splitting tensile strength of concrete, respectively, was noted. Sammy et al. [38] compared normal-strength concrete and high-strength concrete subjected to high temperatures. The 28-day compressive strength of concrete was tested after different exposure times of various temperatures $\left(400,600,800,1000\right.$, and $\left.1200{ }^{\circ} \mathrm{C}\right)$. The compressive strength of concrete containing rubber-modified recycled aggregate was also investigated at elevated temperatures [39].

It is clear from past studies that input parameters directly correlate with output results $[40,41]$. Supervised machine learning approaches also have the capability of incorporating the effect of temperature change, which indicates the positive aspect of these techniques. ML algorithms show a better performance, with a smaller variance, when considering the parameter of temperature change [42]. The performance of ML approaches is associated with several parameters, including the number of parameters and the data that are used to create the model. The novelty of the authors' research approach also includes the addition of another parameter (temperature effect) for predicting the strength of concrete. The ML approaches, and their comparison in terms of their performance, were investigated in this study. This study included the temperature effect, which was used as an input parameter for investigating the performance of the selected ML approaches during the prediction of the compressive strength of concrete.

\section{Research Significance}

This study aimed to forecast the compressive strength of concrete exposed to high temperatures by employing individual and ensemble machine learning algorithms. The decision tree (DT) and artificial neural network (ANN) (as a system), as well as the bagging regressor and gradient boosting regressor (as ensemble machine learning approaches) were used. The novelty of this research involves the investigation of the accuracy level of individual and ensemble ML algorithms, as well as the evaluation of the accuracy level of each approach for predicting the compressive strength of concrete at high temperatures. This study also compares statistical indicators that are used to evaluate the model's accuracy. This study shows that the ensemble algorithms yielded a strong relationship when compared to individual machine learning techniques. Furthermore, the validity and accuracy of all the employed models were evaluated by using the method of k-fold cross-validation and by applying statistical checks. However, sensitivity analysis provides information regarding the contribution of the temperature parameter for predicting compressive strength. The purpose of this research also includes the comparison of the employed machine learning approaches with the techniques adopted in the literature.

\section{Methodology}

\subsection{Supervised Machine Learning (ML) Techniques}

Machine learning algorithms are more commonly applied in civil engineering for predicting the mechanical properties of concrete. Examples of their application are listed in the Table 1. The compressive or flexural strength of concrete can be determined by using the hit and trial method for various ages of concrete samples. To overcome some limitation in this method, we used machine learning algorithms to forecast outcomes for input data. Hao et al. [43] used the support vector machine (SVM) and k-fold crossvalidation to predict the compressive strength of concrete in a marine environment, stating that the SVM performs better when compared to the artificial neural network (ANN) and decision tree (DT). Chengyeo et al. [44] predicted the compressive strength of concrete in a 
wet-dry environment using the backpropagation artificial neural network (BP-ANN). It was shown that the BP-ANN provides better accuracy regarding the actual and predicted results. Hocine et al. [45] applied the ANN model for predicting the compressive strength of limestone filler concrete. The training, testing, and validation of their data provides a strong correlation (exceeding 97\%) with the real data. Behfernia et al. [46] used the ANN and adaptive neuro-based fuzzy inference (ANFIS) to predict the compressive strength of concrete. It was evaluated that the ANN model is a well-organized model for predicting the compressive strength of concrete. Hoang et al. [47] employed efficient machine learning models for predicting the strength of concrete. They proposed that the performance of the trained models of the gradient boosting regressor (GBR) and extreme gradient boosting (XGBoost) were better when compared to the support vector regressor and multilayer perceptron (MLR).

Table 1. Prediction properties using different approaches.

\begin{tabular}{|c|c|c|c|c|c|c|c|}
\hline No. & Algorithm Used & Notation & Data Points & Prediction Properties & Year & $\begin{array}{l}\text { Material } \\
\text { Used }\end{array}$ & References \\
\hline 1. & Support vector machine & SVM & 144 & $\begin{array}{l}\text { Compressive strength } \\
\text { Bearing capacity of }\end{array}$ & 2021 & FA & [48] \\
\hline 2. & Gene expression programming & GEP & 303 & $\begin{array}{c}\text { concrete-filled steel tube } \\
\text { column }\end{array}$ & 2019 & - & [49] \\
\hline 3. & $\begin{array}{l}\text { Data envelopment } \\
\text { analysis }\end{array}$ & DEA & 114 & $\begin{array}{c}\text { Compressive strength Slump } \\
\text { test } \\
\text { L-box test } \\
\text { V-funnel test }\end{array}$ & 2021 & FA & [50] \\
\hline 4. & $\begin{array}{l}\text { Gene expression programming, } \\
\text { artificial neural network, } \\
\text { decision tree }\end{array}$ & $\begin{array}{l}\text { GEP, ANN, } \\
\text { DT }\end{array}$ & 642 & Surface chloride concentration & 2021 & FA & [51] \\
\hline 5. & Support vector machine & SVM & - & $\begin{array}{l}\text { Compressive strength } \\
\text { Slump test }\end{array}$ & 2020 & FA & [52] \\
\hline 6. & Support vector machine & SVM & 115 & $\begin{array}{c}\text { L-box test } \\
\text { V-funnel test }\end{array}$ & 2020 & FA & [53] \\
\hline 7. & Gene expression programming & GEP & 351 & $\begin{array}{l}\text { Compressive strength } \\
\text { Compressive strength }\end{array}$ & 2020 & GGBS & [54] \\
\hline 8. & Gene expression programming & GEP & 54 & Compressive strength & 2019 & $\begin{array}{l}\text { NZ (natural } \\
\text { zeolite) }\end{array}$ & [54] \\
\hline 9. & Gene expression programming & GEP & 357 & Compressive strength & 2020 & - & [55] \\
\hline 10. & $\begin{array}{l}\text { Random forest and gene } \\
\text { expression programming }\end{array}$ & RF and GEP & 357 & Compressive strength & 2020 & - & [56] \\
\hline 11. & Artificial neuron network & ANN & 205 & Compressive strength & 2019 & $\begin{array}{l}\text { FA } \\
\text { GGBFS } \\
\text { SF } \\
\text { RHA }\end{array}$ & [57] \\
\hline 12. & $\begin{array}{c}\text { Intelligent rule-based } \\
\text { enhanced multiclass support } \\
\text { vector machine and fuzzy rules }\end{array}$ & $\begin{array}{l}\text { IREMSVM- } \\
\text { FR with } \\
\text { RSM }\end{array}$ & 114 & Compressive strength & 2019 & FA & [58] \\
\hline 13. & Random forest & RF & 131 & Compressive strength & 2019 & $\begin{array}{l}\text { FA } \\
\text { GGBFS } \\
\text { FA }\end{array}$ & [59] \\
\hline 14. & $\begin{array}{l}\text { Multivariate adaptive } \\
\text { regression spline }\end{array}$ & $\begin{array}{l}\text { M5 } \\
\text { MARS }\end{array}$ & 114 & $\begin{array}{c}\text { Compressive strength } \\
\text { Slump test } \\
\text { L-box test } \\
\text { V-funnel test }\end{array}$ & 2018 & FA & [60] \\
\hline 15. & $\begin{array}{l}\text { Random kitchen sink } \\
\text { algorithm }\end{array}$ & RKSA & 40 & $\begin{array}{c}\text { V-funnel test } \\
\text { J-ring test } \\
\text { Slump test } \\
\text { Compressive strength }\end{array}$ & 2018 & FA & [61] \\
\hline 16. & $\begin{array}{l}\text { Adaptive neuro fuzzy } \\
\text { inference system }\end{array}$ & ANFIS & 55 & Compressive strength & 2018 & - & [62] \\
\hline $\begin{array}{l}17 . \\
18 .\end{array}$ & $\begin{array}{l}\text { Artificial neuron network } \\
\text { Artificial neuron network }\end{array}$ & $\begin{array}{l}\text { ANN } \\
\text { ANN }\end{array}$ & $\begin{array}{c}114 \\
69\end{array}$ & $\begin{array}{l}\text { Compressive strength } \\
\text { Compressive strength }\end{array}$ & $\begin{array}{l}2017 \\
2017\end{array}$ & $\begin{array}{l}\text { FA } \\
\text { FA }\end{array}$ & $\begin{array}{l}{[63]} \\
{[64]}\end{array}$ \\
\hline 19. & $\begin{array}{l}\text { Individual and ensemble } \\
\text { algorithm }\end{array}$ & $\begin{array}{c}\text { GEP, DT, } \\
\text { and bagging }\end{array}$ & 270 & Compressive Strength & 2021 & FA & [42] \\
\hline 20. & $\begin{array}{l}\text { Individual with ensemble } \\
\text { modeling }\end{array}$ & $\begin{array}{c}\text { ANN, } \\
\text { bagging and } \\
\text { boosting }\end{array}$ & 1030 & Compressive strength & 2021 & FA & [65] \\
\hline 21. & Multivariate & MV & 21 & Compressive strength & 2020 & $\begin{array}{l}\text { Crumb } \\
\text { rubber with } \\
\text { SF }\end{array}$ & [66] \\
\hline 22. & Gene expression programming & GEP & 277 & Axial capacity & 2020 & - & [67] \\
\hline 23. & $\begin{array}{c}\text { Adaptive neuro fuzzy } \\
\text { inference system }\end{array}$ & $\begin{array}{l}\text { ANFIS with } \\
\text { ANN }\end{array}$ & 7 & Compressive strength & 2020 & POFA & [68] \\
\hline 24. & $\begin{array}{l}\text { Response surface method, } \\
\text { gene expression programming }\end{array}$ & RSM, GEP & 108 & Compressive strength & 2020 & Steel Fibers & [69] \\
\hline
\end{tabular}




\subsection{Description of the Obtained Data}

The data points used to run the models via machine learning algorithms were obtained from the literature [20,70-77], and can be seen in Appendix A. The data taken from the published article explains the behavior of concrete in a hot environment. Nine parameters were taken as the input parameters, namely, cement, water, fine aggregate, coarse aggregate, fly ash, superplasticizer, nano silica, silica fume, and temperature, while compressive strength was taken as the output parameter. These parameters were employed in Jupiter python software in order to indicate the graphical representation in the form of their relative frequency distributions, which can be seen in Figure 1. It is clear that the model's performance was significantly affected by the input variables. The descriptive analysis, as well as the mathematical indication of the variables used to run the models (with their ranges), are listed in Table 2.
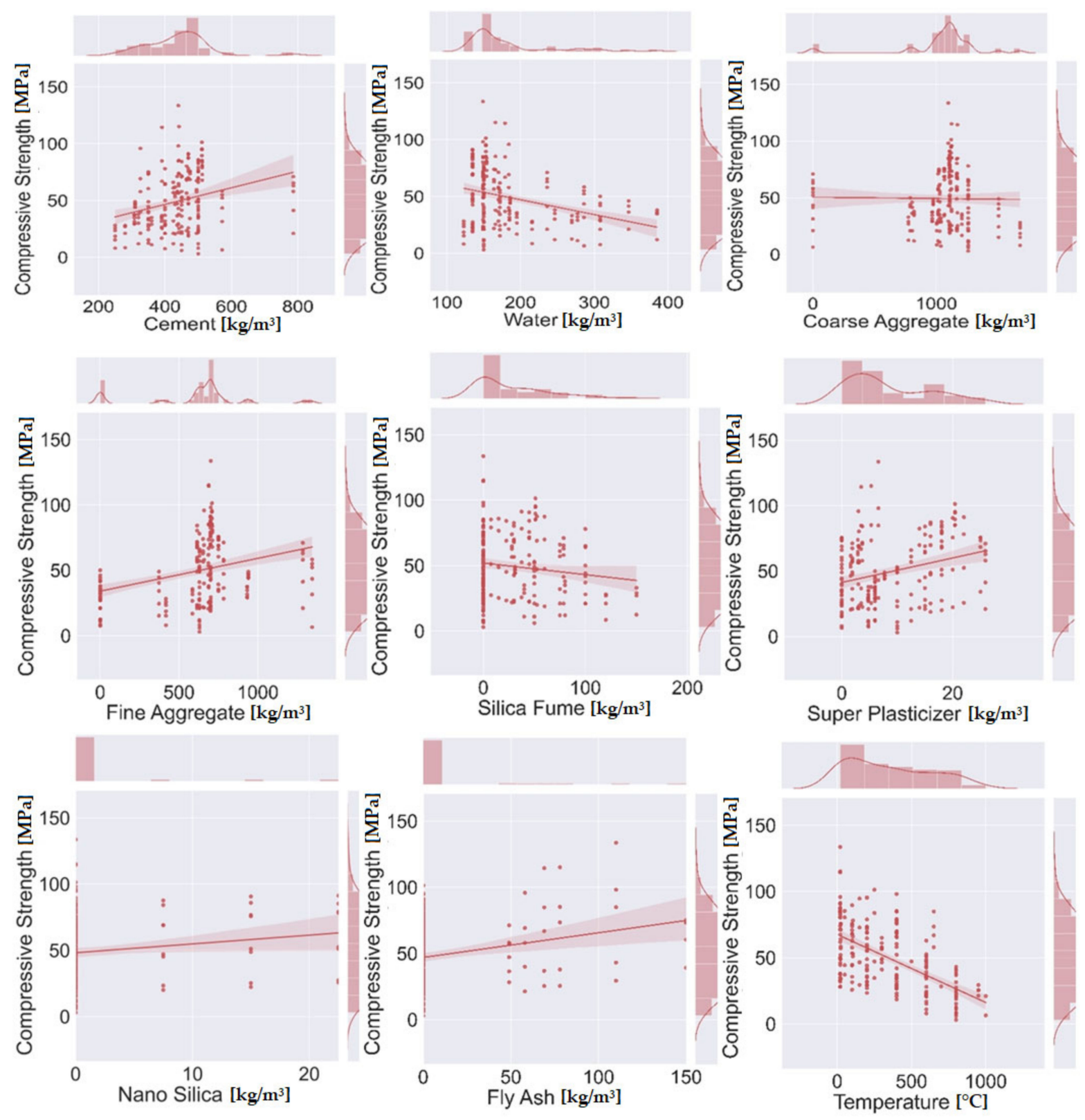

Figure 1. Contour plots showing the relative distribution of the parameters. 
Table 2. Descriptive analysis of the parameters.

\begin{tabular}{|c|c|c|c|c|c|c|c|c|c|}
\hline $\begin{array}{l}\text { Parameters } \\
\text { Description }\end{array}$ & Cement & Water & $\begin{array}{c}\text { Fine } \\
\text { Aggregate }\end{array}$ & $\begin{array}{c}\text { Coarse } \\
\text { Aggregate }\end{array}$ & Fly Ash & $\begin{array}{c}\text { Super } \\
\text { Plasticizer }\end{array}$ & Silica Fume & Nano Silica & Temperature \\
\hline Mean & 437.69 & 182.92 & 610.13 & 1052.13 & 12.65 & 8.58 & 29.32 & 1.74 & 354.52 \\
\hline $\begin{array}{l}\text { Standard } \\
\text { error }\end{array}$ & 6.64 & 4.16 & 22.06 & 21.51 & 2.30 & 0.53 & 2.58 & 0.36 & 19.99 \\
\hline Median & 442.00 & 154.00 & 689.00 & 1110.00 & 0.00 & 6.00 & 7.50 & 0.00 & 300.00 \\
\hline Mode & 500.00 & 150.00 & 0.00 & 1110.00 & 0.00 & 0.00 & 0.00 & 0.00 & 400.00 \\
\hline $\begin{array}{l}\text { Standard } \\
\text { deviation }\end{array}$ & 95.49 & 59.90 & 317.39 & 309.41 & 33.07 & 7.60 & 37.09 & 5.25 & 287.65 \\
\hline $\begin{array}{c}\text { Sample } \\
\text { variance }\end{array}$ & 9118.52 & 3588.58 & $100,736.87$ & $95,735.94$ & 1093.76 & 57.71 & 1375.35 & 27.54 & $82,743.10$ \\
\hline Kurtosis & 3.39 & 2.06 & 0.71 & 5.69 & 7.01 & -0.62 & 1.02 & 8.45 & -1.04 \\
\hline Skewness & 0.98 & 1.67 & -0.40 & -1.97 & 2.74 & 0.74 & 1.26 & 3.08 & 0.47 \\
\hline Range & 536.00 & 262.00 & 1345.00 & 1681.00 & 150.00 & 25.90 & 150.00 & 22.50 & 980.00 \\
\hline Minimum & 250.00 & 123.00 & 0.00 & 0.00 & 0.00 & 0.00 & 0.00 & 0.00 & 20.00 \\
\hline Maximum & 786.00 & 385.00 & 1345.00 & 1681.00 & 150.00 & 25.90 & 150.00 & 22.50 & 1000.00 \\
\hline Sum & $90,601.00$ & $37,864.80$ & $126,297.00$ & $217,790.00$ & 2619.00 & 1776.20 & 6068.60 & 360.00 & $73,386.00$ \\
\hline Count & 207.00 & 207.00 & 207.00 & 207.00 & 207.00 & 207.00 & 207.00 & 207.00 & 207.00 \\
\hline
\end{tabular}

\subsection{Machine Learning Approaches}

This section explains the types of algorithms used for predicting the compressive strength of concrete at high temperatures. The strength property (compressive strength) of concrete was forecasted using both ensemble and individual algorithms. The decision tree, bagging, and gradient boosting techniques were used to run the models. Python coding was used in Anaconda software for all three employed machine learning approaches. The applied algorithms are illustrated in Figure 2.

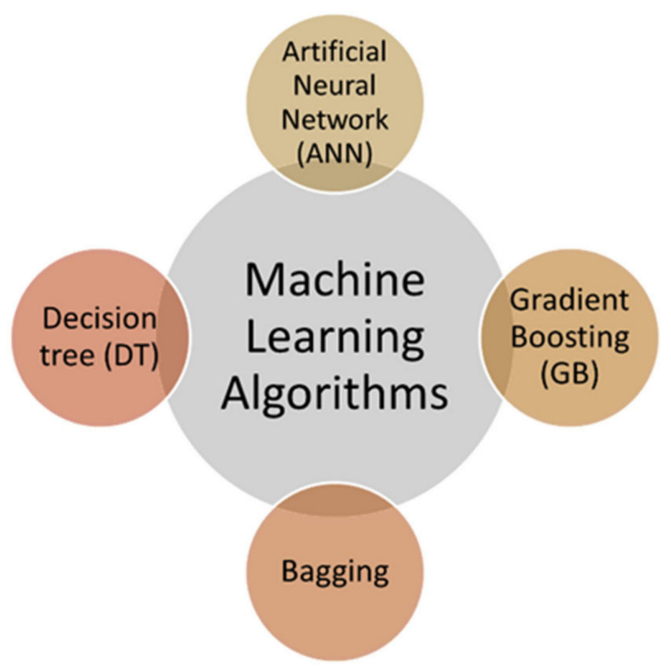

Figure 2. Machine learning techniques used in the research.

A decision tree is a supervised machine learning technique used for the distribution of regression problems, as well as for the classification of problems. The structure of the decision tree is like a flowchart with nodes, branches, and roots. The internal node exhibits a test on an attribute; every branch shows the outcome of the test, while each leaf node provides the indication of the class tag. The classification rule is represented by the path followed from the root to the leaf. Three different types of nodes of decision tree, with three geometric shapes (square, circle, and triangle), are available. It can generally be seen as a simple technique that can be used for understanding and interpreting.

Bagging is also known as bootstrap aggregating, the arrangement of bagging in such a way that can improve the firmness and accuracy of the machine learning algorithms used in the regression and classification. It is normally used to reduce the variances among the actual and predicted results. Bagging can be applied to any type of method but has commonly been applied with decision tree methods. It is also considered to be one of the special cases of the model averaging technique. Bagging is a parallel ensemble machine 
learning approach that gives an explanation about the variance of predicted models by providing supplementary data in the training stage. There are equal chances for each element to appear in the new dataset. Predictive power cannot be improved while altering the training set. The decision tree with bagging is modulated with 20 sub-models to have an optimized value, and as a result a strong adamant output result can be obtained.

Gradient boosting is generally considered and accepted as one of the powerful approaches for creating predictive models. It is an ensemble machine learning algorithm that is normally employed for regression and classification problems. It develops a forecasted model in the form of an ensemble of frail predicted models-normally the decision tree. When the decision tree provides the result as a weak learner, the resulting algorithm will then be considered as a gradient boosting tree. Gradient boosting can also be employed in the field of learning to rank. It is also used for high energy physics in data analysis.

The artificial neural network (ANN) algorithm has a brain-like structure with connected neurons. The ANN is essentially the collection of connected units or nodes (known as artificial neurons), which act as the model of the human brain. These neural networks learn by example of processing. They contain a known "input" and "result", which creating probability-weighted associations among the input and result and are stored within the data structure of the net itself. The application of the ANN in the field of civil engineering is of great interest nowadays, especially for predicting the mechanical properties of concrete. This is due to its high accuracy level of predicting results for the actual strength properties of concrete.

\section{Result and Analysis}

\subsection{Statistical Analysis}

The statistical results for the actual and predicted (using supervised machine learning algorithms) compressive strength of concrete obtained at high temperature, as well as their error distribution, are shown in Figure 3. The accuracy level of the performance of the model was compared with the value of the correlation coefficient $\left(\mathrm{R}^{2}\right)$. The DT (individual algorithm) model appeared to be better, with the value of $\mathrm{R}^{2}$ equal to 0.83 , as depicted in Figure 3a. The model's error distribution can be seen in Figure 3b. The minimum and maximum error values of the DT model were determined at a level of $14.5 \mathrm{MPa}$ and 101.4 MPa, respectively. The average value of the errors was $51.2 \mathrm{MPa}$. However, $50 \%$ data of the errors data lay between 30 and $70 \mathrm{MPa}$, and only $7.1 \%$ data showed as error above $100 \mathrm{MPa}$, as illustrated in Figure $3 \mathrm{~b}$.

The predictive performance of the bagging (ensemble algorithm) model indicates a strong relation with the actual outcomes. The highest value of $R^{2}(0.90)$ was obtained in the case of the bagging regressor. In turn, the values of $\mathrm{R}^{2}$ for the ANN, DT, and GB were equal to $0.82,0.83$, and 0.88 , respectively. These results indicate a high accuracy level of the prediction. The graphical representation of the predicted and actual results of the compressive strength of concrete at high temperatures can be seen in Figure 3c, with its error distribution in Figure 3d. The maximum and minimum error values for the bagging regressor when predicting the strength property of concrete at increased temperatures were equal to 94.1 and $12.95 \mathrm{MPa}$, respectively. However, $59.92 \%$ of the errors data lay between 30 and $70 \mathrm{MPa}$, as shown in Figure 3d.

The gradient boosting (ensemble ML approach) model also indicates a better accuracy in the case of the predictive and actual outcomes for the compressive strength of concrete at high temperatures. In comparison, the performance of gradient boosting was almost similar to the bagging regressor (with less margin for the bagging regressor due to the $\mathrm{R}^{2}$ value being equal to 0.88 ), as shown in Figure 3e. The error distribution is shown in Figure $3 \mathrm{f}$. The average value of the gradient boosting regressor was equal to $50.76 \mathrm{MPa}$, whereas the maximum and minimum error values were 114.5 and $6 \mathrm{MPa}$, respectively. In addition, only $4.76 \%$ of the error data were above $100 \mathrm{MPa}$ for the regressor. 

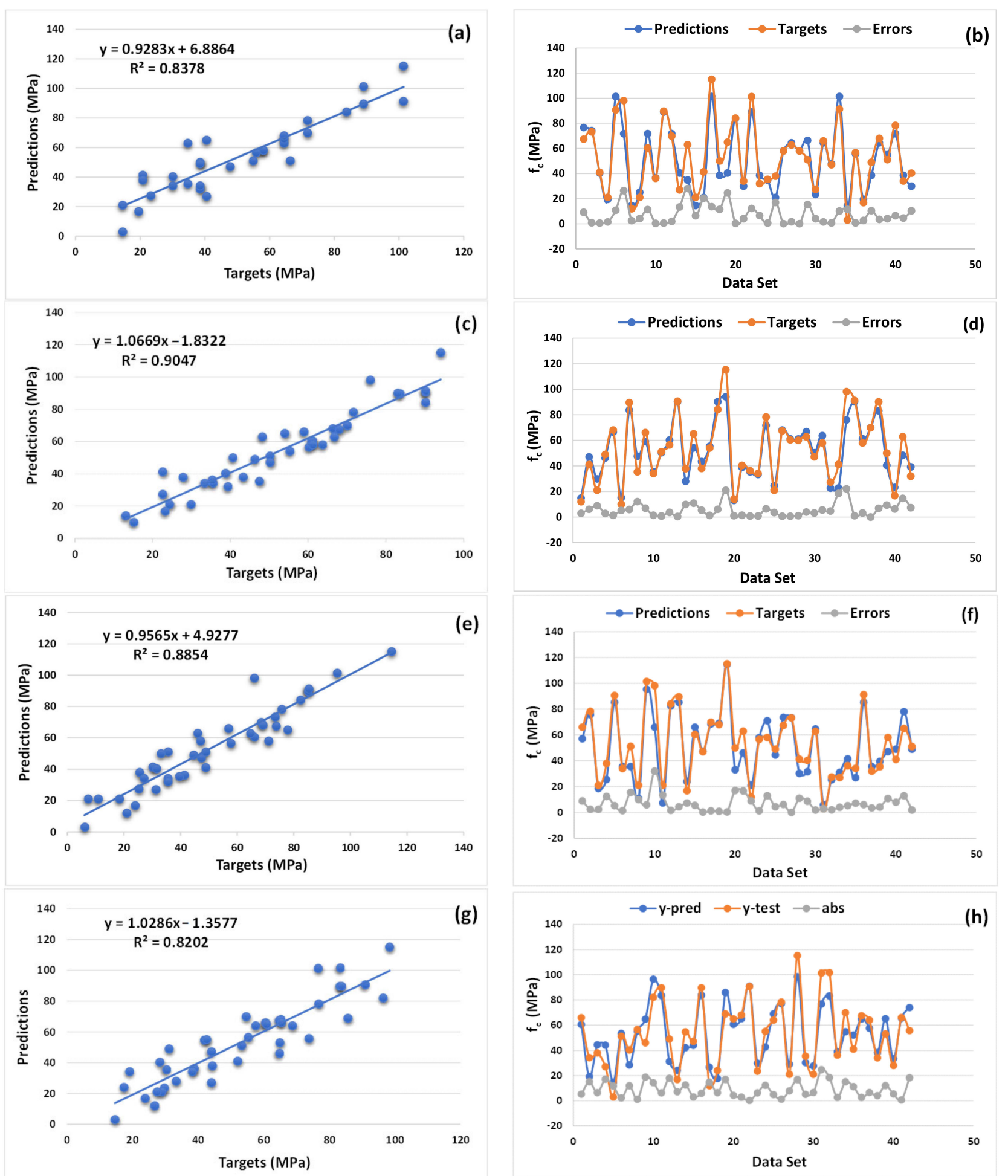

Figure 3. Numerical analysis results showing the relationship between the actual and predicted results, including the error distribution of models: DT (a,b); bagging (c,d); GB (e,f), ANN (g,h).

The same statistical result for the ANN model also indicates the better performance of this model when compared to the DT algorithm. The ANN model indicated a strong relation, with a smaller variance between the actual and predicted outcome, and provided the $\mathrm{R}^{2}$ value equal to 0.82 , as shown in Figure $3 \mathrm{~g}$. The distribution of the errors for the ANN model can be seen in Figure $3 \mathrm{~h}$. The distribution indicates the maximum and minimum values of the error, which were equal to 24.58 and $0.29 \mathrm{MPa}$, respectively. However, the 
average value was equal to $9.158 \mathrm{MPa}$. It was also noted that $57.14 \%$ of the error data lay between 0 to $10 \mathrm{MPa}$, and $19.04 \%$ of the data lay between 10 to $15 \mathrm{MPa}$, with only $2.38 \%$ of the data being above $20 \mathrm{MPa}$.

\section{2. $k$-Fold Cross Validation and Statistical Checks}

To evaluate the model's authentic execution, we adopted the k-fold cross validation approach. This method is normally employed to analyze the actual performance of models. In this test, the data were arranged randomly and divided into 10 groups. Nine groups were allocated for training purposes, and the remaining one was assigned for validation of the model. The average value was obtained by repeating the same process 10 times. The application of the 10-fold cross validation test was used to obtain the most accurate performance of the models. It was also important to apply the statistical checks in order to obtain the performance level of the model. This research also includes the application of the statistical check of the performance of the models with regards to the prediction according to Equations (1)-(5)

$$
\begin{gathered}
\mathrm{RMSE}=\sqrt{\frac{\sum_{i=1}^{n}\left(e x_{i}-m o_{i}\right)^{2}}{n}} \\
\mathrm{MAE}=\frac{\sum_{i=1}^{n}\left|e x_{i}-m o_{i}\right|}{n} \\
\mathrm{RSE}=\frac{\sum_{i=1}^{n}\left(m o_{i-} e x_{i}\right)^{2}}{\sum_{i=1}^{n}\left(\overline{e x}-e x_{i}\right)^{2}} \\
\mathrm{RRMSE}=\frac{1}{e} \sqrt{\frac{\sum_{i=1}^{n}\left(e x_{i}-m o_{i}\right)^{2}}{n}} \\
\mathrm{R}=\frac{\sum_{i=1}^{n}\left(e x_{i}-\overline{e x}_{i}\right)\left(m o_{i}-\overline{m o}_{i}\right)}{\sqrt{\sum_{i=1}^{n}\left(e x_{i}-\overline{e x}_{i}\right)^{2} \sum_{i=1}^{n}\left(m o_{i}-\overline{m o}_{i}\right)^{2}}}
\end{gathered}
$$

where

$e x_{i}=$ the experimental value;

$m o_{i}=$ the predicted value;

$\overline{e x}_{i}=$ the mean experimental value;

$\overline{m o}_{i}=$ the mean predicted value obtained by the model;

$n=$ the number of samples.

The correlation coefficient $\left(\mathrm{R}^{2}\right)$, mean absolute error (MAE), mean square error (MSE), and root mean square error (RMSE) were introduced for evaluating the $k$-fold cross validation, as depicted in Figure 4. The validation process was performed for all the employed (DT, ANN, bagging, and gradient boosting) ML algorithms. The small values of the errors of the bagging model, and at the same time the increased value of the correlation coefficient $\left(\mathrm{R}^{2}\right)$, indicated a better accuracy level when compared to the ANN, DT, and GB. The details of the analysis used for the $\mathrm{k}$-fold cross validation process are included in Table 3.

In addition, the statistical checks, including mean absolute error (MAE), mean square error (MSE), and root mean square error (RMSE), were evaluated for all the machine learning approaches (Table 4). A smaller value of the error increased the value of the correlation coefficient $\left(\mathrm{R}^{2}\right)$. The bagging regressor provided the value of MAE equal to $5.65 \mathrm{MPa}$, which was less than the MAE value of the DT (7.54 MPa), ANN (9.15 MPa), and GB (6.93 MPa). Similarly, the MSE and RMSE of the ANN was higher than the DT, bagging, and $G B$, while the $R^{2}$ value of the ANN was lower than that of the other regressors. 

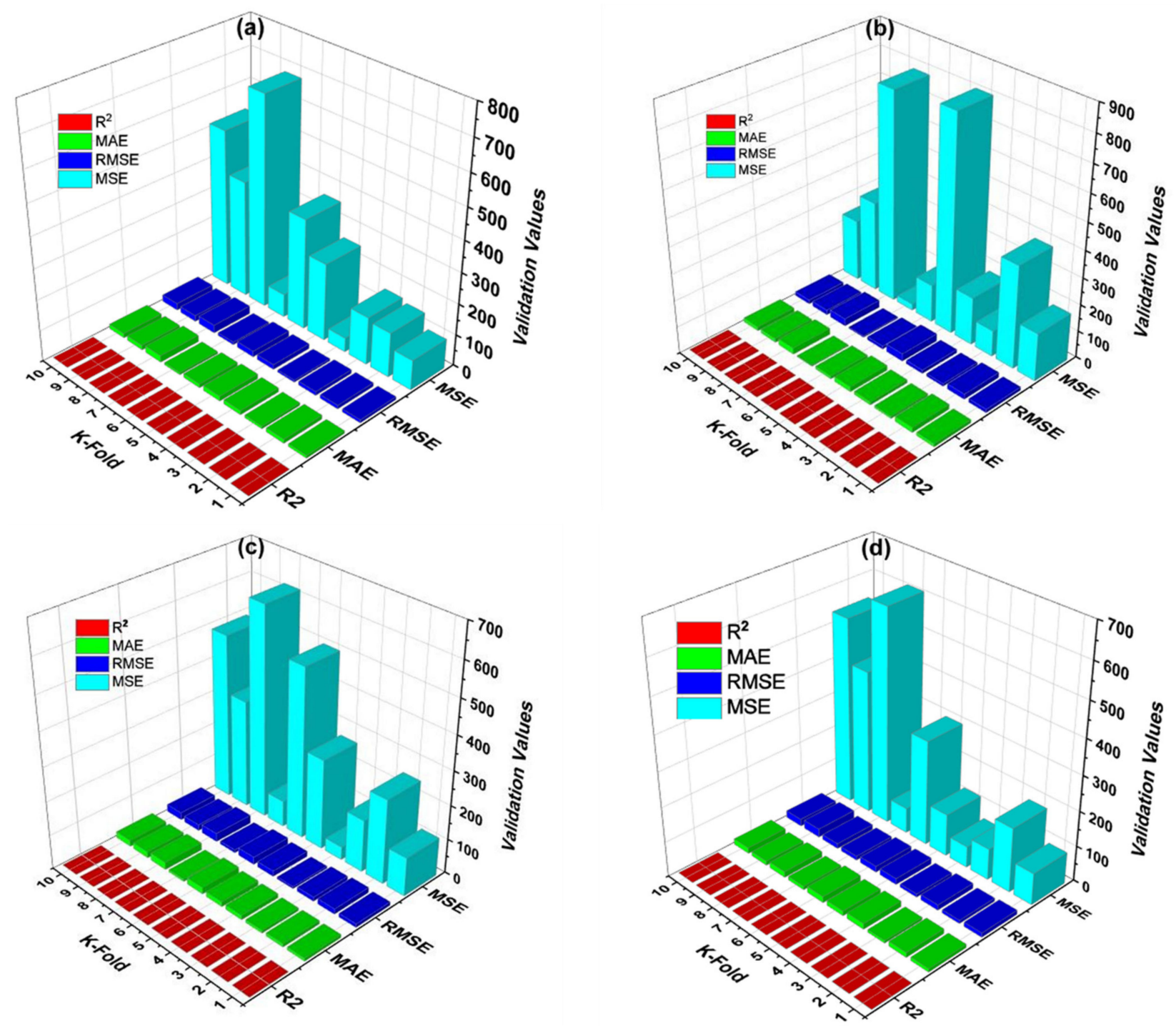

Figure 4. Statistical indication of the k-fold cross validation. DT (a); bagging (b); GB (c); ANN (d).

Table 3. Analysis of the k-fold cross-validation.

\begin{tabular}{|c|c|c|c|c|c|c|c|c|c|c|c|c|c|c|c|c|}
\hline \multicolumn{4}{|c|}{ Decision Tree } & \multicolumn{2}{|c|}{ Bagging } & \multicolumn{6}{|c|}{ GB } & \multirow[b]{2}{*}{$\mathbf{R}^{2}$} & \multicolumn{4}{|c|}{ ANN } \\
\hline k-Fold & MAE & MSE & RMSE & $\mathbf{R}^{2}$ & MAE & MSE & RMSE & $\mathbf{R}^{2}$ & MAE & MSE & RMSE & & MAE & MSE & RMSE & $\mathbf{R}^{2}$ \\
\hline 1. & 8.65 & 96.27 & 9.81 & 0.76 & 12.26 & 178.85 & 13.37 & 0.48 & 8.94 & 113.11 & 10.64 & 0.75 & 9.75 & 90.48 & 12.48 & 0.83 \\
\hline 2. & 12.89 & 143.44 & 11.98 & 0.80 & 18.53 & 384.74 & 19.61 & 0.54 & 9.77 & 247.83 & 15.74 & 0.82 & 13.86 & 183.85 & 9.39 & 0.84 \\
\hline 3. & 8.28 & 153.70 & 12.40 & 0.70 & 8.17 & 97.45 & 9.87 & 0.77 & 8.47 & 153.30 & 12.38 & 0.57 & 7.50 & 128.58 & 15.39 & 0.62 \\
\hline 4. & 13.30 & 45.73 & 6.76 & 0.50 & 11.94 & 178.89 & 13.37 & 0.58 & 12.83 & 38.32 & 6.19 & 0.87 & 16.49 & 60.28 & 9.48 & 0.49 \\
\hline 5. & 15.80 & 250.80 & 15.84 & 0.82 & 18.60 & 806.46 & 28.40 & 0.38 & 14.22 & 265.39 & 16.29 & 0.79 & 13.59 & 199.39 & 17.49 & 0.76 \\
\hline 6. & 12.27 & 358.78 & 18.94 & 0.19 & 10.57 & 141.22 & 11.88 & 0.76 & 18.86 & 501.43 & 22.39 & 0.42 & 17.39 & 300.49 & 17.39 & 0.17 \\
\hline 7. & 7.04 & 75.20 & 8.67 & 0.12 & 3.66 & 23.85 & 4.88 & 0.47 & 7.01 & 76.66 & 8.76 & 0.11 & 10.49 & 72.48 & 11.94 & 0.15 \\
\hline 8. & 21.35 & 682.29 & 26.12 & 0.03 & 23.16 & 785.78 & 28.03 & 0.07 & 21.36 & 620.66 & 24.91 & 0.12 & 16.49 & 612.49 & 14.49 & 0.04 \\
\hline 9. & 15.15 & 378.37 & 19.45 & 0.29 & 14.23 & 339.29 & 18.42 & 0.03 & 18.24 & 318.46 & 17.85 & 0.31 & 12.49 & 409.38 & 24.49 & 0.27 \\
\hline 10. & 14.88 & 513.31 & 22.66 & 0.03 & 15.27 & 231.50 & 15.22 & 0.33 & 18.20 & 485.66 & 22.04 & 0.63 & 16.39 & 532.48 & 20.38 & 0.05 \\
\hline
\end{tabular}

Moreover, the statistical representation of the $\mathrm{k}$-fold cross validation, including the correlation coefficient and errors, is presented in Figure 4. The average value of $\mathrm{R}^{2}$ for the DT was 0.42 , with its minimum and maximum $\mathrm{R}^{2}$ values being equal to 0.03 and 0.82 , respectively (Figure $4 \mathrm{a})$. The average $\mathrm{R}^{2}$ value of the bagging regressor was equal to 0.44 , with its minimum and maximum $R^{2}$ values being equal to 0.03 and 0.77 (Figure $4 b$ ). Similarly, the average $\mathrm{R}^{2}$ value of the gradient boosting was equal to 0.54 , with its minimum and maximum values being 0.11 and 0.87 , respectively (Figure $4 \mathrm{c}$ ). The maximum and minimum values of $\mathrm{R}^{2}$ for the ANN were 0.84 and 0.037 , respectively, while the average 
value was 0.42 (Figure 4d). The average values of each error (MAE, MSE, RMSE) for the DT were equal to 12.96, 269.79, and 15.26 MPa, respectively (Figure 4a); these average error values for the bagging were $13.64,316.80$, and $16.31 \mathrm{MPa}$, respectively (Figure $4 \mathrm{~b}$ ). The same trend was also observed for the GB regressor, which had an average value of MAE equal to 13.79 $\mathrm{MPa}$, with the values of MSE and RMSE being 282.08 and $15.72 \mathrm{MPa}$, respectively (as shown in Figure 4c). In addition, the average values of the errors (MAE, MSE, RMSE) for the ANN model were 13.44, 258.98, and 15.28 MPa, respectively (as presented in Figure 4d).

Table 4. Statistical checks.

\begin{tabular}{cccc}
\hline Machine Learning Algorithms & MAE (MPa) & MSE (MPa) & RMSE (MPa) \\
\hline Decision tree (DT) & 7.54 & 112.23 & 10.79 \\
Bagging & 5.65 & 61.08 & 7.81 \\
Gradient boosting (GB) & 6.93 & 85.47 & 9.24 \\
Artificial neural network (ANN) & 9.15 & 121.66 & 11.03 \\
\hline
\end{tabular}

\subsection{Sensitivity Analysis of the Compressive Strength of Concrete at High Temperatures}

Sensitivity analysis was conducted in order to check the parameters that have a significant effect on the prediction of the compressive strength of concrete at high temperatures, as shown in Figure 5. Every variable used to run the model plays its role in predicting the strength of concrete. However, cement was the decisive factor that influenced the prediction of the strength of concrete. Its influence on the obtained results was estimated at $32 \%$. In turn, the influence of fly ash, superplasticizers, silica fume, water, temperature, nano silica, fine aggregate, and coarse aggregate was estimated at the levels of $16 \%, 15 \%$, $14 \%, 2 \%, 6 \%, 3 \%, 10 \%$, and $2 \%$, respectively. The result of the sensitivity analyses depends on the number of input parameters and the number of data points used to run the model. However, the contribution of each parameter is identified by the employed ML algorithm. The results of these analyses vary due to the different proportions of the concrete mix and the addition of new input parameters.

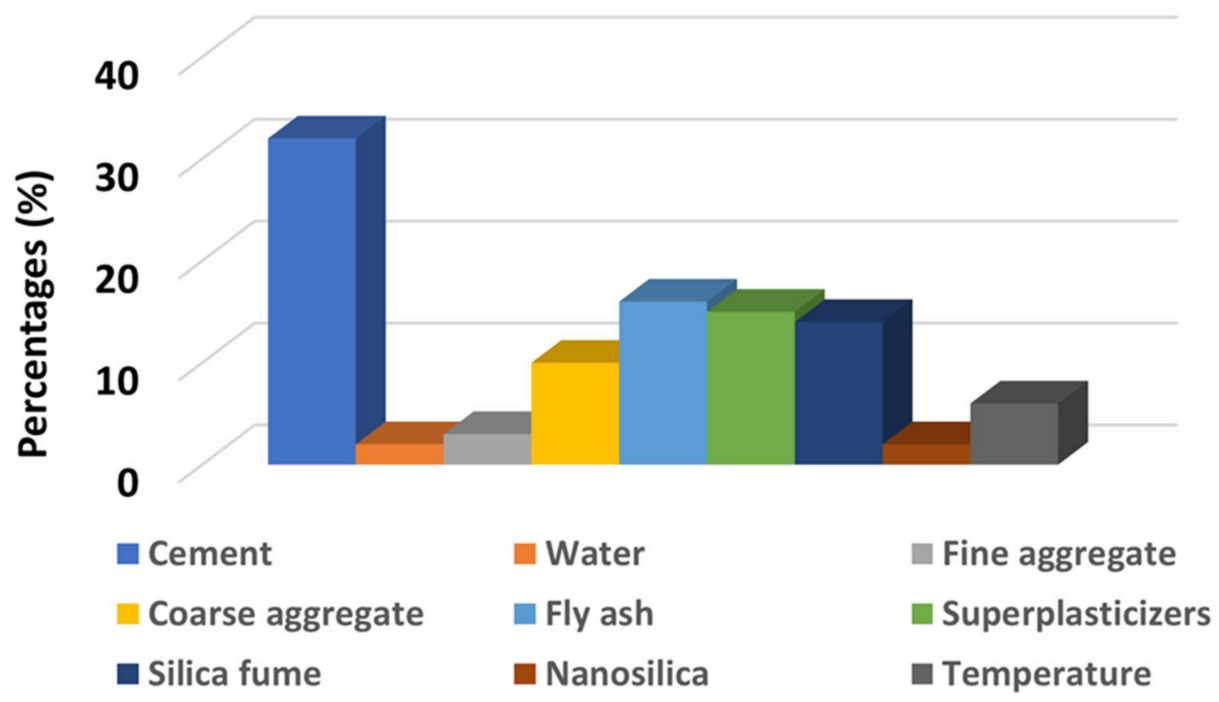

Figure 5. Bar chart indicating the performance of input parameters with regards to predicting of the compressive strength of concrete.

\subsection{Discussion}

This research shows a comparison of the performance of the various models with the experimental results of the compressive strength of concrete exposed to high temperatures. Ensemble (bagging, gradient boosting) and individual (ANN, DT) supervised machine learning algorithms were used for prediction purposes. The bagging regressor had a 
better prediction performance when compared to the ANN, DT, and GB. However, it is difficult to analyze and recommend the best machine learning regressor for predicting results for various topics because the performance of the models is directly affected by the input parameters and the data points used to run the model. However, ensemble machine learning techniques normally uses the weak learner by making the sub-models, which can be trained on data and uses the optimization to obtain a maximum value of $\mathrm{R}^{2}$. The performance of the 20 sub-models of the bagging and GB regressor, with their correlation coefficient $\left(R^{2}\right)$ values, can be seen in Figure 5. Thus, according to the literature, the performance of ensemble models shows more accurate results when compared to individual machine learning approaches. Previous studies also proven that the ensemble ML approaches such as bagging, boosting, and AdaBoost have better response towards the prediction of outcomes.

Moreover, it is also important to know about the performance of each parameter with regards to predicting outcomes. The sensitivity analysis provides information of how an individual parameter contributes towards the predicting of outcomes. The result of sensitivity analysis for this study can be seen in Figure 6. This study was also based on statistical checks, the validation process, and sensitivity analysis in order to verify the execution level of the evaluated ML techniques. This research could be beneficial with regards to reducing costs and minimizing the time consumed during the hit and trial method for achieving the desired strength of concrete. In addition, the research results can also be used in other fields of engineering for predicting required outcomes. It was shown that the ensemble modeling provides a better performance when compared to the other methods. Therefore, this technique is preferred for forecasting results in the case of related issues.

(a)

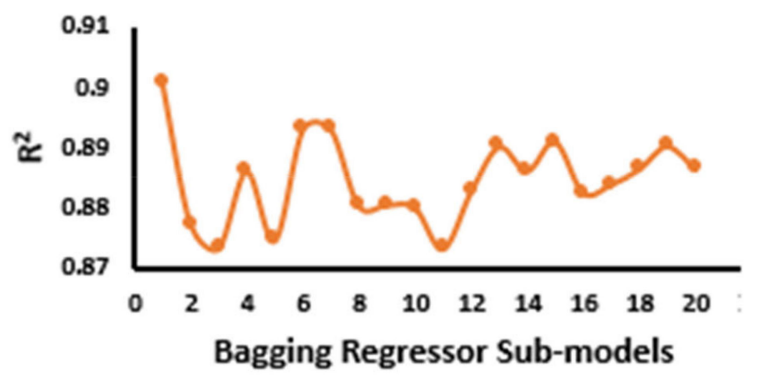

(b)

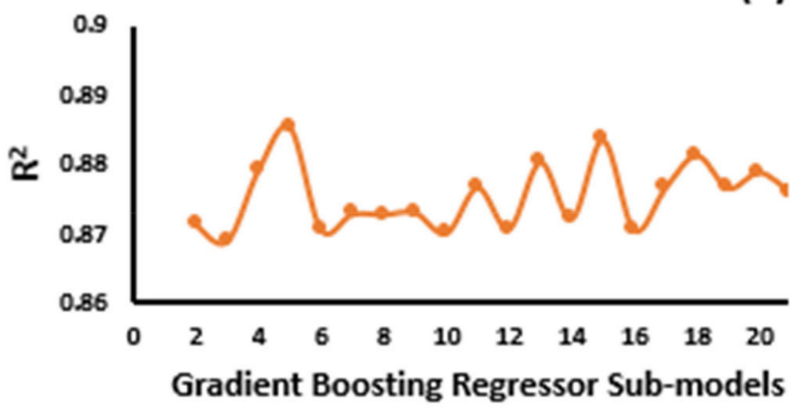

Figure 6. Sub-models representing the correlation coefficient $\left(R^{2}\right)$ values. Bagging (a); GB (b).

\section{Conclusions and Future Recommendations}

This research provides information about the predictive determination of the compressive strength of concrete at high temperatures using individual and ensemble supervised machine learning approaches. The application of the ML techniques for predicting the performance of concrete is quite an effective approach as it shows a high-level accuracy when compared to the actual result. It usually takes a large amount of time ( 28 days) to determine the strength of concrete. In turn, ML algorithms play an important role in reducing this time, and also save a large amount of the costs and efforts associated with the conducting of experimental works. In this research, the decision tree (DT) and ANN algorithms were selected from the individual techniques, while the bagging and gradient boosting (GB) regressors were used as ensemble algorithms for forecasting the strength of concrete at high temperatures. The bagging technique was most effective and had the highest correlation coefficient value. The lesser values of the errors (MAE of 5.65 MPa, MSE of $61.08 \mathrm{MPa}$, RMSE of 7.81) from the statistical checks for the bagging were also the indication of its better performance as opposed to ANN, DT, and GB. Practically, it is impossible to evaluate the effect of temperature on the mechanical properties of concrete prepared with various type of mixes. However, the temperature and other related effects 
such as humidity can also be added as input parameters for running the models to obtain the required output. The following conclusions form this study can be drawn: the ensemble algorithms (bagging and GB) performed well when predicting the compressive strength of concrete-not only at normal temperature, but also at high temperatures.

(a) The performance of the models can be affected by input parameters. Taking into account the thermal aspect (being the main consideration of the paper), we found that the ensemble models showed less discrepancy between actual and predicted results.

(b) The accuracy level of the bagging and GB regressors was also confirmed using the $\mathrm{k}$-fold cross validation process.

(c) The contribution of each parameter with regards to predicting the outcome was evaluated by means of sensitivity analysis.

(d) This study describes the positive role of the supervised ML approaches in the field of civil engineering. The application of these techniques can be successfully adopted to predict the mechanical properties of concrete without spending time on the experimental work in the laboratory. It was also observed that the ensemble machine learning algorithms indicate a strong relation between actual and forecasted results when compared to individual algorithms.

(e) The high accuracy of the models can also be achieved by increasing the data points, as number of data points have high influence on the model's outcome.

(f) The performance of the models can also be evaluated on the basis of practical work performed in a laboratory in order to understand the difference level between the actual and predicted result.

(g) The variance can be reduced by splitting more than 20 sub-models (in the ensemble techniques) for training on data and optimization would give the maximum $\mathrm{R}^{2}$ value.

It should be underlined that it is difficult to recommend or say about any approach directly on few trails that will provide the most accurate result, while the other techniques (such as AdaBoost Regressor) can be used for the prediction of outcomes for making comparisons.

Author Contributions: A.A.-modelling, conceptualization, and writing the original and revised draft; K.A.O.- supervision, visualization, review and writing the original and revised draft; M.M.review, writing revised draft, funding and supervision; F.F. - review and visualization; I.M.—data analysis, writing and review; A.N.-investigation and data analysis. All authors have read and agreed to the published version of the manuscript.

Funding: This project is funded by COMSATS University Islamabad and Cracow University of Technology.

Institutional Review Board Statement: Not applicable.

Informed Consent Statement: Not applicable.

Data Availability Statement: The data presented in this article are available within the article.

Acknowledgments: This project is supported by COMSATS University Islamabad. The authors would like to thank all persons, especially Waqas Ahmad who played a positive role for completion of this work.

Conflicts of Interest: The authors declare no conflict of interest. 
Appendix A

Table A1. Data points used in modeling.

\begin{tabular}{|c|c|c|c|c|c|c|c|c|c|}
\hline $\begin{array}{l}\text { Cement } \\
\left(\mathrm{kg} / \mathrm{m}^{3}\right)\end{array}$ & $\begin{array}{c}\text { Water } \\
\left(\mathrm{kg} / \mathrm{m}^{3}\right)\end{array}$ & $\begin{array}{c}\text { Fine } \\
\text { Aggregate } \\
\left(\mathrm{kg} / \mathrm{m}^{3}\right)\end{array}$ & $\begin{array}{c}\text { Coarse } \\
\text { Aggregate } \\
\left(\mathrm{kg} / \mathrm{m}^{3}\right)\end{array}$ & $\begin{array}{l}\text { Fly Ash } \\
\left(\mathrm{kg} / \mathrm{m}^{3}\right)\end{array}$ & $\begin{array}{c}\text { Super } \\
\text { Plasticizer } \\
\left(\mathrm{kg} / \mathrm{m}^{3}\right)\end{array}$ & $\begin{array}{l}\text { Silica Fume } \\
\left(\mathrm{kg} / \mathrm{m}^{3}\right)\end{array}$ & $\begin{array}{c}\text { Nano Silica } \\
\left(\mathrm{kg} / \mathrm{m}^{3}\right)\end{array}$ & Temperature ${ }^{\circ} \mathrm{C}$ & $\begin{array}{l}\text { Compressive } \\
\text { Strength } \\
\text { (MPa) }\end{array}$ \\
\hline 250 & 123 & 417 & 1681 & 0 & 0 & 0 & 0 & 20 & 28.16 \\
\hline 250 & 123 & 417 & 1681 & 0 & 0 & 0 & 0 & 200 & 23.4 \\
\hline 250 & 123 & 417 & 1681 & 0 & 0 & 0 & 0 & 400 & 18.57 \\
\hline 250 & 123 & 417 & 1681 & 0 & 0 & 0 & 0 & 600 & 15.26 \\
\hline 250 & 123 & 417 & 1681 & 0 & 0 & 0 & 0 & 800 & 8.01 \\
\hline 350 & 172 & 373 & 1507 & 0 & 0 & 0 & 0 & 20 & 48.99 \\
\hline 350 & 172 & 373 & 1507 & 0 & 0 & 0 & 0 & 100 & 44.58 \\
\hline 350 & 172 & 373 & 1507 & 0 & 0 & 0 & 0 & 400 & 34.12 \\
\hline 350 & 172 & 373 & 1507 & 0 & 0 & 0 & 0 & 600 & 24.41 \\
\hline 350 & 172 & 373 & 1507 & 0 & 0 & 0 & 0 & 800 & 15.24 \\
\hline 500 & 385 & 0 & 820 & 0 & 6 & 0 & 0 & 20 & 38 \\
\hline 500 & 385 & 0 & 820 & 0 & 6 & 0 & 0 & 200 & 36 \\
\hline 500 & 385 & 0 & 820 & 0 & 6 & 0 & 0 & 800 & 12 \\
\hline 450 & 346.5 & 0 & 805 & 0 & 6 & 50 & 0 & 20 & 46 \\
\hline 450 & 346.5 & 0 & 805 & 0 & 6 & 50 & 0 & 200 & 41.5 \\
\hline 450 & 346.5 & 0 & 805 & 0 & 6 & 50 & 0 & 400 & 36.2 \\
\hline 400 & 308 & 0 & 790 & 0 & 6 & 100 & 0 & 20 & 50 \\
\hline 400 & 308 & 0 & 790 & 0 & 6 & 100 & 0 & 400 & 42 \\
\hline 400 & 308 & 0 & 790 & 0 & 6 & 100 & 0 & 800 & 21 \\
\hline 350 & 269.5 & 0 & 775 & 0 & 6 & 150 & 0 & 20 & 33 \\
\hline 350 & 269.5 & 0 & 775 & 0 & 6 & 150 & 0 & 200 & 29 \\
\hline 350 & 269.5 & 0 & 775 & 0 & 6 & 150 & 0 & 800 & 12.5 \\
\hline 400 & 308 & 0 & 1038 & 0 & 4.8 & 0 & 0 & 20 & 32 \\
\hline 400 & 308 & 0 & 1038 & 0 & 4.8 & 0 & 0 & 200 & 29.5 \\
\hline 400 & 308 & 0 & 1038 & 0 & 4.8 & 0 & 0 & 400 & 28.5 \\
\hline 360 & 277.2 & 0 & 1028 & 0 & 4.8 & 40 & 0 & 20 & 35 \\
\hline 360 & 277.2 & 0 & 1028 & 0 & 4.8 & 40 & 0 & 400 & 29 \\
\hline 360 & 277.2 & 0 & 1028 & 0 & 4.8 & 40 & 0 & 800 & 11 \\
\hline 320 & 246.4 & 0 & 1015 & 0 & 4.8 & 80 & 0 & 20 & 38 \\
\hline 320 & 246.4 & 0 & 1015 & 0 & 4.8 & 80 & 0 & 200 & 35 \\
\hline 320 & 246.4 & 0 & 1015 & 0 & 4.8 & 80 & 0 & 800 & 12 \\
\hline 280 & 215.6 & 0 & 1005 & 0 & 4.8 & 120 & 0 & 20 & 28 \\
\hline 280 & 215.6 & 0 & 1005 & 0 & 4.8 & 120 & 0 & 200 & 27 \\
\hline 280 & 215.6 & 0 & 1005 & 0 & 4.8 & 120 & 0 & 400 & 21 \\
\hline 500 & 135 & 700 & 1110 & 0 & 14 & 30 & 0 & 20 & 82.47 \\
\hline 500 & 135 & 700 & 1110 & 0 & 14 & 30 & 0 & 600 & 42.58 \\
\hline 500 & 135 & 700 & 1110 & 0 & 14 & 30 & 0 & 800 & 22.03 \\
\hline 500 & 135 & 700 & 1110 & 0 & 15 & 22.5 & 7.5 & 20 & 84.14 \\
\hline 500 & 135 & 700 & 1110 & 0 & 15 & 22.5 & 7.5 & 400 & 68.99 \\
\hline 500 & 135 & 700 & 1110 & 0 & 15 & 22.5 & 7.5 & 800 & 23.39 \\
\hline 500 & 135 & 700 & 1110 & 0 & 16 & 15 & 15 & 20 & 85.84 \\
\hline 500 & 135 & 700 & 1110 & 0 & 16 & 15 & 15 & 400 & 76.62 \\
\hline 500 & 135 & 700 & 1110 & 0 & 16 & 15 & 15 & 800 & 25.28 \\
\hline 500 & 135 & 700 & 1110 & 0 & 18 & 7.5 & 22.5 & 20 & 85.21 \\
\hline 500 & 135 & 700 & 1110 & 0 & 18 & 7.5 & 22.5 & 400 & 79.12 \\
\hline 500 & 135 & 700 & 1110 & 0 & 18 & 7.5 & 22.5 & 600 & 51.11 \\
\hline 470 & 135 & 700 & 1110 & 0 & 16 & 60 & 0 & 20 & 87.38 \\
\hline 470 & 135 & 700 & 1110 & 0 & 16 & 60 & 0 & 600 & 47.39 \\
\hline 470 & 135 & 700 & 1110 & 0 & 16 & 60 & 0 & 800 & 18.82 \\
\hline 470 & 135 & 700 & 1110 & 0 & 18 & 52.5 & 7.5 & 20 & 87.61 \\
\hline 470 & 135 & 700 & 1110 & 0 & 18 & 52.5 & 7.5 & 400 & 68.94 \\
\hline 470 & 135 & 700 & 1110 & 0 & 18 & 52.5 & 7.5 & 800 & 20.06 \\
\hline 470 & 135 & 700 & 1110 & 0 & 20 & 45 & 15 & 20 & 90.6 \\
\hline 470 & 135 & 700 & 1110 & 0 & 20 & 45 & 15 & 400 & 75.71 \\
\hline 470 & 135 & 700 & 1110 & 0 & 20 & 45 & 15 & 600 & 51.12 \\
\hline 470 & 135 & 700 & 1110 & 0 & 22 & 37.5 & 22.5 & 400 & 78.22 \\
\hline 470 & 135 & 700 & 1110 & 0 & 22 & 37.5 & 22.5 & 600 & 52.49 \\
\hline 470 & 135 & 700 & 1110 & 0 & 22 & 37.5 & 22.5 & 800 & 25.72 \\
\hline 326 & 184 & 659 & 1124 & 58 & 3 & 0 & 0 & 20 & 95.8 \\
\hline 326 & 184 & 659 & 1124 & 58 & 3 & 0 & 0 & 650 & 57.9 \\
\hline 326 & 184 & 659 & 1124 & 58 & 3 & 0 & 0 & 800 & 40 \\
\hline 326 & 184 & 659 & 1124 & 58 & 3 & 0 & 0 & 950 & 21.3 \\
\hline 391 & 179 & 689 & 1172 & 69 & 3.5 & 0 & 0 & 20 & 114.4 \\
\hline 391 & 179 & 689 & 1172 & 69 & 3.5 & 0 & 0 & 400 & 84.8 \\
\hline 391 & 179 & 689 & 1172 & 69 & 3.5 & 0 & 0 & 800 & 36.8 \\
\hline 391 & 179 & 689 & 1172 & 69 & 3.5 & 0 & 0 & 950 & 25.4 \\
\hline 442 & 166 & 689 & 1125 & 78 & 5.3 & 0 & 0 & 20 & 115.1 \\
\hline 442 & 166 & 689 & 1125 & 78 & 5.3 & 0 & 0 & 400 & 85.2 \\
\hline 442 & 166 & 689 & 1125 & 78 & 5.3 & 0 & 0 & 650 & 73.5 \\
\hline 442 & 166 & 689 & 1125 & 78 & 5.3 & 0 & 0 & 950 & 25.5 \\
\hline 440 & 149 & 702 & 1099 & 110 & 6.6 & 0 & 0 & 20 & 133.6 \\
\hline 440 & 149 & 702 & 1099 & 110 & 6.6 & 0 & 0 & 400 & 98.1 \\
\hline 440 & 149 & 702 & 1099 & 110 & 6.6 & 0 & 0 & 650 & 84.9 \\
\hline 440 & 149 & 702 & 1099 & 110 & 6.6 & 0 & 0 & 800 & 43.1 \\
\hline
\end{tabular}


Table A1. Cont.

\begin{tabular}{|c|c|c|c|c|c|c|c|c|c|}
\hline $\begin{array}{l}\text { Cement } \\
\left(\mathrm{kg} / \mathrm{m}^{3}\right)\end{array}$ & $\begin{array}{c}\text { Water } \\
\left(\mathrm{kg} / \mathrm{m}^{3}\right)\end{array}$ & $\begin{array}{c}\text { Fine } \\
\text { Aggregate } \\
\left(\mathrm{kg} / \mathrm{m}^{3}\right)\end{array}$ & $\begin{array}{c}\text { Coarse } \\
\text { Aggregate } \\
\left(\mathrm{kg} / \mathrm{m}^{3}\right)\end{array}$ & $\begin{array}{l}\text { Fly Ash } \\
\left(\mathrm{kg} / \mathrm{m}^{3}\right)\end{array}$ & $\begin{array}{c}\text { Super } \\
\text { Plasticizer } \\
\left(\mathrm{kg} / \mathrm{m}^{3}\right)\end{array}$ & $\begin{array}{l}\text { Silica Fume } \\
\left(\mathrm{kg} / \mathrm{m}^{3}\right)\end{array}$ & $\begin{array}{c}\text { Nano Silica } \\
\left(\mathrm{kg} / \mathrm{m}^{3}\right)\end{array}$ & Temperature ${ }^{\circ} \mathrm{C}$ & $\begin{array}{l}\text { Compressive } \\
\text { Strength } \\
\text { (MPa) }\end{array}$ \\
\hline 437 & 170 & 783 & 1016 & 49 & 1.9 & 0 & 0 & 300 & 57.2 \\
\hline 437 & 170 & 783 & 1016 & 49 & 1.9 & 0 & 0 & 400 & 58 \\
\hline 437 & 170 & 783 & 1016 & 49 & 1.9 & 0 & 0 & 500 & 47.2 \\
\hline 437 & 170 & 783 & 1016 & 49 & 1.9 & 0 & 0 & 600 & 36.5 \\
\hline 437 & 170 & 783 & 1016 & 49 & 1.9 & 0 & 0 & 700 & 28.3 \\
\hline 500 & 150 & 630 & 1260 & 0 & 10 & 0 & 0 & 22 & 49 \\
\hline 500 & 150 & 630 & 1260 & 0 & 10 & 0 & 0 & 300 & 41 \\
\hline 500 & 150 & 630 & 1260 & 0 & 10 & 0 & 0 & 400 & 23 \\
\hline 500 & 150 & 630 & 1260 & 0 & 10 & 0 & 0 & 600 & 8 \\
\hline 500 & 150 & 630 & 1260 & 0 & 10 & 0 & 0 & 800 & 3 \\
\hline 450 & 150 & 630 & 1260 & 0 & 10 & 50 & 0 & 22 & 52 \\
\hline 450 & 150 & 630 & 1260 & 0 & 10 & 50 & 0 & 105 & 53 \\
\hline 450 & 150 & 630 & 1260 & 0 & 10 & 50 & 0 & 400 & 27 \\
\hline 450 & 150 & 630 & 1260 & 0 & 10 & 50 & 0 & 600 & 11 \\
\hline 450 & 150 & 630 & 1260 & 0 & 10 & 50 & 0 & 800 & 6 \\
\hline 425 & 150 & 630 & 1260 & 0 & 12.5 & 75 & 0 & 22 & 57 \\
\hline 425 & 150 & 630 & 1260 & 0 & 12.5 & 75 & 0 & 105 & 66 \\
\hline 425 & 150 & 630 & 1260 & 0 & 12.5 & 75 & 0 & 300 & 61 \\
\hline 425 & 150 & 630 & 1260 & 0 & 12.5 & 75 & 0 & 600 & 21 \\
\hline 425 & 150 & 630 & 1260 & 0 & 12.5 & 75 & 0 & 800 & 12 \\
\hline 400 & 150 & 630 & 1260 & 0 & 15 & 100 & 0 & 22 & 64 \\
\hline 400 & 150 & 630 & 1260 & 0 & 15 & 100 & 0 & 105 & 78 \\
\hline 400 & 150 & 630 & 1260 & 0 & 15 & 100 & 0 & 300 & 65 \\
\hline 400 & 150 & 630 & 1260 & 0 & 15 & 100 & 0 & 400 & 37 \\
\hline 400 & 150 & 630 & 1260 & 0 & 15 & 100 & 0 & 800 & 21 \\
\hline 308 & 185 & 933 & 968 & 0 & 6 & 0 & 0 & 20 & 37.5 \\
\hline 308 & 185 & 933 & 968 & 0 & 6 & 0 & 0 & 100 & 31.5 \\
\hline 308 & 185 & 933 & 968 & 0 & 6 & 0 & 0 & 150 & 29.4 \\
\hline 308 & 185 & 933 & 968 & 0 & 6 & 0 & 0 & 200 & 29.2 \\
\hline 308 & 185 & 933 & 968 & 0 & 6 & 0 & 0 & 250 & 34.7 \\
\hline 310 & 186 & 940 & 976 & 0 & 7.7 & 31 & 0 & 20 & 44.5 \\
\hline 310 & 186 & 940 & 976 & 0 & 7.7 & 31 & 0 & 50 & 44.3 \\
\hline 310 & 186 & 940 & 976 & 0 & 7.7 & 31 & 0 & 150 & 46.5 \\
\hline 310 & 186 & 940 & 976 & 0 & 7.7 & 31 & 0 & 200 & 48.9 \\
\hline 310 & 186 & 940 & 976 & 0 & 7.7 & 31 & 0 & 250 & 47.1 \\
\hline 512 & 154 & 711 & 1106 & 0 & 18 & 0 & 0 & 20 & 80.6 \\
\hline 512 & 154 & 711 & 1106 & 0 & 18 & 0 & 0 & 50 & 80.5 \\
\hline 512 & 154 & 711 & 1106 & 0 & 18 & 0 & 0 & 100 & 67.8 \\
\hline 512 & 154 & 711 & 1106 & 0 & 18 & 0 & 0 & 200 & 78.9 \\
\hline 512 & 154 & 711 & 1106 & 0 & 18 & 0 & 0 & 250 & 83.7 \\
\hline 511 & 153 & 709 & 1122 & 0 & 20.4 & 51 & 0 & 20 & 85.1 \\
\hline 511 & 153 & 709 & 1122 & 0 & 20.4 & 51 & 0 & 50 & 85.2 \\
\hline 511 & 153 & 709 & 1122 & 0 & 20.4 & 51 & 0 & 100 & 89.6 \\
\hline 511 & 153 & 709 & 1122 & 0 & 20.4 & 51 & 0 & 150 & 94.6 \\
\hline 511 & 153 & 709 & 1122 & 0 & 20.4 & 51 & 0 & 250 & 101.3 \\
\hline 500 & 150 & 750 & 1068 & 0 & 0 & 0 & 0 & 100 & 75.3 \\
\hline 500 & 150 & 750 & 1068 & 0 & 0 & 0 & 0 & 200 & 68.9 \\
\hline 500 & 150 & 750 & 1068 & 0 & 0 & 0 & 0 & 400 & 66 \\
\hline 500 & 150 & 750 & 1068 & 0 & 0 & 0 & 0 & 600 & 35.4 \\
\hline 350 & 150 & 750 & 1023 & 150 & 0 & 0 & 0 & 23 & 75.2 \\
\hline 350 & 150 & 750 & 1023 & 150 & 0 & 0 & 0 & 200 & 73.3 \\
\hline 350 & 150 & 750 & 1023 & 150 & 0 & 0 & 0 & 400 & 60.4 \\
\hline 350 & 150 & 750 & 1023 & 150 & 0 & 0 & 0 & 600 & 39.2 \\
\hline 475 & 150 & 750 & 1065 & 0 & 25 & 0 & 0 & 23 & 75.7 \\
\hline 475 & 150 & 750 & 1065 & 0 & 25 & 0 & 0 & 100 & 75.4 \\
\hline 475 & 150 & 750 & 1065 & 0 & 25 & 0 & 0 & 400 & 68.5 \\
\hline 475 & 150 & 750 & 1065 & 0 & 25 & 0 & 0 & 600 & 34.2 \\
\hline 390 & 195 & 585 & 1209 & 0 & 0 & 0 & 0 & 23 & 34.1 \\
\hline 390 & 195 & 585 & 1209 & 0 & 0 & 0 & 0 & 100 & 35.6 \\
\hline 390 & 195 & 585 & 1209 & 0 & 0 & 0 & 0 & 200 & 31.6 \\
\hline 390 & 195 & 585 & 1209 & 0 & 0 & 0 & 0 & 600 & 16.8 \\
\hline 390 & 195 & 585 & 1209 & 0 & 0 & 0 & 0 & 400 & 26.6 \\
\hline 572 & 286 & 1345 & 0 & 0 & 0 & 0 & 0 & 600 & 43.4 \\
\hline 786 & 236 & 1286 & 0 & 0 & 25.9 & 78.6 & 0 & 800 & 41.3 \\
\hline 572 & 286 & 1345 & 0 & 0 & 0 & 0 & 0 & 23 & 58.3 \\
\hline 572 & 286 & 1345 & 0 & 0 & 0 & 0 & 0 & 200 & 55 \\
\hline 572 & 286 & 1345 & 0 & 0 & 0 & 0 & 0 & 400 & 52.2 \\
\hline 572 & 286 & 1345 & 0 & 0 & 0 & 0 & 0 & 800 & 31.5 \\
\hline 572 & 286 & 1345 & 0 & 0 & 0 & 0 & 0 & 1000 & 6.5 \\
\hline 786 & 236 & 1286 & 0 & 0 & 25.9 & 78.6 & 0 & 23 & 71 \\
\hline 786 & 236 & 1286 & 0 & 0 & 25.9 & 78.6 & 0 & 200 & 58 \\
\hline 786 & 236 & 1286 & 0 & 0 & 25.9 & 78.6 & 0 & 400 & 65.4 \\
\hline 786 & 236 & 1286 & 0 & 0 & 25.9 & 78.6 & 0 & 600 & 62.9 \\
\hline 786 & 236 & 1286 & 0 & 0 & 25.9 & 78.6 & 0 & 1000 & 21 \\
\hline 430 & 172 & 687 & 1030 & 0 & 1.6 & 0 & 0 & 20 & 61.8 \\
\hline 430 & 172 & 687 & 1030 & 0 & 1.6 & 0 & 0 & 100 & 53.3 \\
\hline 430 & 172 & 687 & 1030 & 0 & 1.6 & 0 & 0 & 200 & 55.5 \\
\hline 430 & 172 & 687 & 1030 & 0 & 1.6 & 0 & 0 & 300 & 46.5 \\
\hline 430 & 172 & 687 & 1030 & 0 & 1.6 & 0 & 0 & 600 & 20.6 \\
\hline
\end{tabular}


Table A1. Cont.

\begin{tabular}{|c|c|c|c|c|c|c|c|c|c|}
\hline $\begin{array}{l}\text { Cement } \\
\left(\mathrm{kg} / \mathrm{m}^{3}\right)\end{array}$ & $\begin{array}{c}\text { Water } \\
\left(\mathrm{kg} / \mathrm{m}^{3}\right)\end{array}$ & $\begin{array}{c}\text { Fine } \\
\text { Aggregate } \\
\left(\mathrm{kg} / \mathrm{m}^{3}\right)\end{array}$ & $\begin{array}{l}\text { Coarse } \\
\text { Aggregate } \\
\left(\mathrm{kg} / \mathrm{m}^{3}\right)\end{array}$ & $\begin{array}{l}\text { Fly Ash } \\
\left(\mathrm{kg} / \mathrm{m}^{3}\right)\end{array}$ & $\begin{array}{c}\text { Super } \\
\text { Plasticizer } \\
\left(\mathrm{kg} / \mathrm{m}^{3}\right)\end{array}$ & $\begin{array}{l}\text { Silica Fume } \\
\left(\mathrm{kg} / \mathrm{m}^{3}\right)\end{array}$ & $\begin{array}{c}\text { Nano Silica } \\
\left(\mathrm{kg} / \mathrm{m}^{3}\right)\end{array}$ & Temperature ${ }^{\circ} \mathrm{C}$ & $\begin{array}{l}\text { Compressive } \\
\text { Strength } \\
\text { (MPa) }\end{array}$ \\
\hline 441 & 164 & 653 & 1115 & 0 & 2.9 & 28 & 0 & 100 & 62.8 \\
\hline 441 & 164 & 653 & 1115 & 0 & 2.9 & 28 & 0 & 200 & 64.7 \\
\hline 441 & 164 & 653 & 1115 & 0 & 2.9 & 28 & 0 & 300 & 56.5 \\
\hline 441 & 164 & 653 & 1115 & 0 & 2.9 & 28 & 0 & 600 & 21.8 \\
\hline 495 & 149 & 615 & 1168 & 0 & 1.9 & 0 & 0 & 20 & 67.4 \\
\hline 495 & 149 & 615 & 1168 & 0 & 1.9 & 0 & 0 & 200 & 59.7 \\
\hline 495 & 149 & 615 & 1168 & 0 & 1.9 & 0 & 0 & 300 & 49 \\
\hline 495 & 149 & 615 & 1168 & 0 & 1.9 & 0 & 0 & 600 & 21 \\
\hline 465 & 149 & 615 & 1168 & 0 & 3.1 & 30 & 0 & 20 & 80.3 \\
\hline 465 & 149 & 615 & 1168 & 0 & 3.1 & 30 & 0 & 100 & 68 \\
\hline 465 & 149 & 615 & 1168 & 0 & 3.1 & 30 & 0 & 300 & 56.5 \\
\hline 465 & 149 & 615 & 1168 & 0 & 3.1 & 30 & 0 & 600 & 23.4 \\
\hline 450 & 149 & 615 & 1168 & 0 & 3.7 & 45 & 0 & 20 & 84.2 \\
\hline 450 & 149 & 615 & 1168 & 0 & 3.7 & 45 & 0 & 100 & 70.8 \\
\hline 450 & 149 & 615 & 1168 & 0 & 3.7 & 45 & 0 & 200 & 71.7 \\
\hline 250 & 123 & 417 & 1681 & 0 & 0 & 0 & 0 & 100 & 25.74 \\
\hline 350 & 172 & 373 & 1507 & 0 & 0 & 0 & 0 & 200 & 40.35 \\
\hline 500 & 385 & 0 & 820 & 0 & 6 & 0 & 0 & 400 & 34.5 \\
\hline 450 & 346.5 & 0 & 805 & 0 & 6 & 50 & 0 & 800 & 21 \\
\hline 400 & 308 & 0 & 790 & 0 & 6 & 100 & 0 & 200 & 44 \\
\hline 350 & 269.5 & 0 & 775 & 0 & 6 & 150 & 0 & 400 & 27 \\
\hline 400 & 308 & 0 & 1038 & 0 & 4.8 & 0 & 0 & 800 & 7.5 \\
\hline 360 & 277.2 & 0 & 1028 & 0 & 4.8 & 40 & 0 & 200 & 32 \\
\hline 320 & 246.4 & 0 & 1015 & 0 & 4.8 & 80 & 0 & 400 & 30 \\
\hline 280 & 215.6 & 0 & 1005 & 0 & 4.8 & 120 & 0 & 800 & 8.5 \\
\hline 500 & 135 & 700 & 1110 & 0 & 14 & 30 & 0 & 400 & 69.87 \\
\hline 500 & 135 & 700 & 1110 & 0 & 15 & 22.5 & 7.5 & 600 & 45.23 \\
\hline 500 & 135 & 700 & 1110 & 0 & 16 & 15 & 15 & 600 & 48.79 \\
\hline 500 & 135 & 700 & 1110 & 0 & 18 & 7.5 & 22.5 & 800 & 27.38 \\
\hline 470 & 135 & 700 & 1110 & 0 & 16 & 60 & 0 & 400 & 69.86 \\
\hline 470 & 135 & 700 & 1110 & 0 & 18 & 52.5 & 7.5 & 600 & 47.07 \\
\hline 470 & 135 & 700 & 1110 & 0 & 20 & 45 & 15 & 800 & 22.32 \\
\hline 470 & 135 & 700 & 1110 & 0 & 22 & 37.5 & 22.5 & 20 & 91.24 \\
\hline 326 & 184 & 659 & 1124 & 58 & 3 & 0 & 0 & 400 & 69.2 \\
\hline 391 & 179 & 689 & 1172 & 69 & 3.5 & 0 & 0 & 650 & 66.9 \\
\hline 442 & 166 & 689 & 1125 & 78 & 5.3 & 0 & 0 & 800 & 37.9 \\
\hline 440 & 149 & 702 & 1099 & 110 & 6.6 & 0 & 0 & 950 & 29.4 \\
\hline 437 & 170 & 783 & 1016 & 49 & 1.9 & 0 & 0 & 20 & 71.2 \\
\hline 500 & 150 & 630 & 1260 & 0 & 10 & 0 & 0 & 105 & 51 \\
\hline 450 & 150 & 630 & 1260 & 0 & 10 & 50 & 0 & 300 & 49 \\
\hline 425 & 150 & 630 & 1260 & 0 & 12.5 & 75 & 0 & 400 & 32 \\
\hline 400 & 150 & 630 & 1260 & 0 & 15 & 100 & 0 & 600 & 28 \\
\hline 308 & 185 & 933 & 968 & 0 & 6 & 0 & 0 & 50 & 37.2 \\
\hline 310 & 186 & 940 & 976 & 0 & 7.7 & 31 & 0 & 100 & 44.1 \\
\hline 512 & 154 & 711 & 1106 & 0 & 18 & 0 & 0 & 150 & 72.8 \\
\hline 511 & 153 & 709 & 1122 & 0 & 20.4 & 51 & 0 & 200 & 95.3 \\
\hline 500 & 150 & 750 & 1068 & 0 & 0 & 0 & 0 & 23 & 75.5 \\
\hline 350 & 150 & 750 & 1023 & 150 & 0 & 0 & 0 & 100 & 73.7 \\
\hline 475 & 150 & 750 & 1065 & 0 & 25 & 0 & 0 & 200 & 73.4 \\
\hline 441 & 164 & 653 & 1115 & 0 & 2.9 & 28 & 0 & 20 & 73.9 \\
\hline 495 & 149 & 615 & 1168 & 0 & 1.9 & 0 & 0 & 100 & 57.6 \\
\hline 465 & 149 & 615 & 1168 & 0 & 3.1 & 30 & 0 & 200 & 69 \\
\hline 450 & 149 & 615 & 1168 & 0 & 3.7 & 45 & 0 & 300 & 57.9 \\
\hline 450 & 149 & 615 & 1168 & 0 & 3.7 & 45 & 0 & 600 & 22.6 \\
\hline
\end{tabular}

\section{References}

1. Bigdeli, Y.; Barbato, M. Use of a low-cost concrete-like fluorogypsum-based blend for applications in underwater and coastal protection structures. In Proceedings of the OCEANS 2017-Anchorage Conference, Anchorage, AK, USA, 18-21 September 2017; pp. 1-5. Available online: https:/ / ieeexplore.ieee.org/abstract/document/8232181 (accessed on 5 May 2021).

2. Reiter, L.; Wangler, T.; Anton, A.; Flatt, R.J. Setting on demand for digital concrete-Principles, measurements, chemistry, validation. Cem. Concr. Res. 2020, 132, 106047. [CrossRef]

3. Amran, Y.M.; Alyousef, R.; Alabduljabbar, H.; El-Zeadani, M. Clean production and properties of geopolymer concrete; A review. J. Clean. Prod. 2020, 251, 119679. [CrossRef]

4. Dong, B.; Wang, F.; Abadikhah, H.; Hao, L.Y.; Xu, X.; Khan, S.A.; Wang, G.; Agathopoulos, S. Simple fabrication of concrete with remarkable self-cleaning ability, robust superhydrophobicity, tailored porosity, and highly thermal and sound insulation. ACS Appl. Mater. Interfaces 2019, 11, 42801-42807. [CrossRef]

5. Chica, L.; Alzate, A. Cellular concrete review: New trends for application in construction. Constr. Build. Mater. 2019, $200,637-647$. [CrossRef]

6. Arora, A.; Almujaddidi, A.; Kianmofrad, F.; Mobasher, B.; Neithalath, N. Material design of economical ultra-high performance concrete (UHPC) and evaluation of their properties. Cem. Concr. Compos. 2019, 104, 103346. [CrossRef] 
7. Farooq, F.; Akbar, A.; Khushnood, R.A.; Muhammad, W.L.B.; Rehman, S.K.U.; Javed, M.F. Experimental investigation of hybrid carbon nanotubes and graphite nanoplatelets on rheology, shrinkage, mechanical, and microstructure of SCCM. Materials 2020, 13, 230. [CrossRef]

8. Khan, M.; Ali, M. Improvement in concrete behavior with fly ash, silica-fume and coconut fibres. Constr. Build. Mater. 2019, 203, 174-187. [CrossRef]

9. Ahmad, W.; Farooq, S.H.; Usman, M.; Khan, M.; Ahmad, A.; Aslam, F.; Al Yousef, R.; Al Abduljabbar, H.; Sufian, M. Effect of coconut fiber length and content on properties of high strength concrete. Materials 2020, 13, 1075. [CrossRef] [PubMed]

10. Bostanci, S.C. Use of waste marble dust and recycled glass for sustainable concrete production. J. Clean. Prod. 2020, 251, 119785. [CrossRef]

11. Gupta, S.; Kua, H.W.; Pang, S.D. Effect of biochar on mechanical and permeability properties of concrete exposed to elevated temperature. Constr. Build. Mater. 2020, 234, 117338. [CrossRef]

12. Karahan, O. Transport properties of high volume fly ash or slag concrete exposed to high temperature. Constr. Build. Mater. 2017, 152, 898-906. [CrossRef]

13. Hager, I. Behaviour of cement concrete at high temperature. Bull. Pol. Acad. Sci. Tech. Sci. 2013, 61, 145-154. [CrossRef]

14. Khan, M.; Cao, M.; Chaopeng, X.; Ali, M. Experimental and analytical study of hybrid fiber reinforced concrete prepared with basalt fiber under high temperature. Fire Mater. 2021. [CrossRef]

15. Pimienta, P.; Hager, I. Mechanical Behaviour of HPC at High Temperature. Available online: https://www.researchgate.net/ publication/293226828_Mechanical_properties_of_hpc_at_high_temperatures (accessed on 14 June 2021).

16. Li, L.; Khan, M.; Bai, C.; Shi, K. Uniaxial tensile behavior, flexural properties, empirical calculation and microstructure of multi-scale fiber reinforced cement-based material at elevated temperature. Materials 2021, 14, 1827. [CrossRef]

17. Noumowe, A.; Carre, H.; Daoud, A.; Toutanji, H. High-strength self-compacting concrete exposed to fire test. J. Mater. Civ. Eng. 2006, 18, 754-758. [CrossRef]

18. Ma, Q.; Guo, R.; Zhao, Z.; Lin, Z.; He, K. Mechanical properties of concrete at high temperature-A review. Constr. Build. Mater. 2015, 93, 371-383. [CrossRef]

19. Khan, U.A.; Jahanzaib, H.M.; Khan, M.; Ali, M. Improving the tensile energy absorption of high strength natural fiber reinforced concrete with fly-ash for bridge girders. Key Eng. Mater. 2018, 765, 335-342. [CrossRef]

20. Husem, M. The effects of high temperature on compressive and flexural strengths of ordinary and high-performance concrete. Fire Saf. J. 2006, 41, 155-163. [CrossRef]

21. Bodnarova, L. Effect of high temperatures on cement composite materials in concrete structures. Acta Geodyn. Geomater. 2013, 10, 173-180. [CrossRef]

22. Tanyildizi, H.; Coşkun, A. Performance of lightweight concrete with silica fume after high temperature. Constr. Build. Mater. 2008, 22, 2124-2129. [CrossRef]

23. Chan, Y.; Luo, X.; Sun, W. Compressive strength and pore structure of high-performance concrete after exposure to high temperature up to $800^{\circ} \mathrm{C}$. Cem. Concr. Res. 2000, 30, 247-251. [CrossRef]

24. Janotka, I.; Nürnbergerová, T.; Nad, L. Behaviour of high-strength concrete with dolomitic aggregate at high temperatures. Mag. Concr. Res. 2000, 52, 399-409. [CrossRef]

25. Kim, J.-K.; Han, S.H.; Song, Y.C. Effect of temperature and aging on the mechanical properties of concrete: Part I. Experimental results. Cem. Concr. Res. 2002, 32, 1087-1094. [CrossRef]

26. Masaki, K.; Maki, I. Effect of prolonged heating at elevated temperatures on the phase composition and textures of Portland cement clinker. Cem. Concr. Res. 2002, 32, 931-934. [CrossRef]

27. Memon, S.A.; Shah, S.F.A.; Khushnood, R.A.; Baloch, W.L. Durability of sustainable concrete subjected to elevated temperature A review. Constr. Build. Mater. 2019, 199, 435-455. [CrossRef]

28. Handoo, S.; Agarwal, S. Physicochemical, mineralogical, and morphological characteristics of concrete exposed to elevated temperatures. Cem. Concr. Res. 2002, 32, 1009-1018. [CrossRef]

29. An, J.; Mikhaylov, A.; Richter, U.H. Trade war effects: Evidence from sectors of energy and resources in Africa. Heliyon 2020, 6, e05693. [CrossRef]

30. An, J.; Mikhaylov, A. Russian energy projects in South Africa. J. Energy S. Afr. 2020, 31, 58-64. [CrossRef]

31. Nguyen, K.T.; Navaratnam, S.; Mendis, P.; Zhang, G.K.; Barnett, J.; Wang, H. Fire safety of composites in prefabricated buildings: From fibre reinforced polymer to textile reinforced concrete. Compos. Part. B Eng. 2020, 187, 107815. [CrossRef]

32. Naser, M.Z.; Seitllari, A. Concrete under fire: An assessment through intelligent pattern recognition. Eng. Comput. 2020, 36, 1915-1928. [CrossRef]

33. Cao, M.; Li, L.; Yin, H.; Ming, X. Microstructure and strength of calcium carbonate (CaCO3) whisker reinforced cement paste after exposed to high temperatures. Fire Technol. 2019, 55, 1983-2003. [CrossRef]

34. Roy, T.; Matsagar, V. Mechanics of damage in reinforced concrete member under post-blast fire scenario. Structures 2021, 31, 740-760. [CrossRef]

35. Malik, M.; Bhattacharyya, S.K.; Barai, S.V. Microstructural changes in concrete: Postfire scenario. J. Mater. Civ. Eng. 2021, 33, 04020462. [CrossRef]

36. Nin Chan, S.Y.; Luo, X.; Sun, W. Effect of high temperature and cooling regimes on the compressive strength and pore properties of high performance concrete. Constr. Build. Mater. 2000, 14, 261-266. [CrossRef] 
37. Tanyildizi, H.; Coşkun, A. The effect of high temperature on compressive strength and splitting tensile strength of structural lightweight concrete containing fly ash. Constr. Build. Mater. 2008, 22, 2269-2275. [CrossRef]

38. Chan, S.Y.N.; Peng, G.-F.; Chan, J.K.W. Comparison between high strength concrete and normal strength concrete subjected to high temperature. Mater. Struct. 1996, 29, 616-619. [CrossRef]

39. Tang, Y.; Feng, W.; Feng, W.; Chen, J.; Bao, D.; Li, L. Compressive properties of rubber-modified recycled aggregate concrete subjected to elevated temperatures. Constr. Build. Mater. 2021, 268, 121181. [CrossRef]

40. Khan, M.A.; Zafar, A.; Farooq, F.; Javed, M.F.; Alyousef, R.; Alabduljabbar, H.; Khan, M.I. Geopolymer Concrete Compressive Strength via Artificial Neural Network, Adaptive Neuro Fuzzy Interface System, and Gene Expression Programming With K-Fold Cross Validation. Front. Mater. 2021, 8, 621163. [CrossRef]

41. Fang, Z.; Roy, K.; Chen, B.; Sham, C.-W.; Hajirasouliha, I.; Lim, J.B. Deep learning-based procedure for structural design of cold-formed steel channel sections with edge-stiffened and un-stiffened holes under axial compression. Thin Walled Struct. 2021, 166, 108076. [CrossRef]

42. Ahmad, A.; Farooq, F.; Niewiadomski, P.; Ostrowski, K.; Akbar, A.; Aslam, F.; Alyousef, R. Prediction of compressive strength of fly ash based concrete using individual and ensemble algorithm. Materials 2021, 14, 794. [CrossRef]

43. Ling, H.; Qian, C.; Kang, W.; Liang, C.; Chen, H. Combination of support vector machine and K-fold cross validation to predict compressive strength of concrete in marine environment. Constr. Build. Mater. 2019, 206, 355-363. [CrossRef]

44. Liang, C.; Qian, C.; Chen, H.; Kang, W. Prediction of compressive strength of concrete in wet-dry environment by BP artificial neural networks. Adv. Mater. Sci. Eng. 2018, 2018,1-11. [CrossRef]

45. Ayat, H.; Kellouche, Y.; Ghrici, M.; Boukhatem, B. Compressive strength prediction of limestone filler concrete using artificial neural networks. Adv. Comput. Des. 2018, 3, 289-302. [CrossRef]

46. Behfarnia, K.; Khademi, F. A comprehensive study on the concrete compressive strength estimation using artificial neural network and adaptive neuro-fuzzy inference system. Int. J. Optim. Civ. Eng. 2017, 7, 71-80.

47. Nguyen, H.; Vu, T.; Vo, T.P.; Thai, H.-T. Efficient machine learning models for prediction of concrete strengths. Constr. Build. Mater. 2021, 266, 120950. [CrossRef]

48. Huang, J.; Sun, Y.; Zhang, J. Reduction of computational error by optimizing SVR kernel coefficients to simulate concrete compressive strength through the use of a human learning optimization algorithm. Eng. Comput. 2021, 1, 1-18. [CrossRef]

49. Sarir, P.; Chen, J.; Asteris, P.G.; Armaghani, D.J.; Tahir, M.M. Developing GEP tree-based, neuro-swarm, and whale optimization models for evaluation of bearing capacity of concrete-filled steel tube columns. Eng. Comput. 2021, 37, 1-19. [CrossRef]

50. Balf, F.R.; Kordkheili, H.M.; Kordkheili, A.M. A new method for predicting the ingredients of Self-Compacting Concrete (SCC) including Fly Ash (FA) using Data Envelopment Analysis (DEA). Arab. J. Sci. Eng. 2021, 46, 4439-4460. [CrossRef]

51. Ahmad, A.; Farooq, F.; Ostrowski, K.; Śliwa-Wieczorek, K.; Czarnecki, S. Application of novel machine learning techniques for predicting the surface chloride concentration in concrete containing waste material. Materials 2021, 14, 2297. [CrossRef] [PubMed]

52. Azimi-Pour, M.; Eskandari-Naddaf, H.; Pakzad, A. Linear and non-linear SVM prediction for fresh properties and compressive strength of high volume fly ash self-compacting concrete. Constr. Build. Mater. 2020, 230, 117021. [CrossRef]

53. Saha, P.; Debnath, P.; Thomas, P. Prediction of fresh and hardened properties of self-compacting concrete using support vector regression approach. Neural Comput. Appl. 2020, 32, 7995-8010. [CrossRef]

54. Shahmansouri, A.A.; Bengar, H.A.; Jahani, E. Predicting compressive strength and electrical resistivity of eco-friendly concrete containing natural zeolite via GEP algorithm. Constr. Build. Mater. 2019, 229, 116883. [CrossRef]

55. Aslam, F.; Farooq, F.; Amin, M.N.; Khan, K.; Waheed, A.; Akbar, A.; Javed, M.F.; Alyousef, R.; Alabdulijabbar, H. Applications of gene expression programming for estimating compressive strength of high-strength concrete. Adv. Civ. Eng. 2020, 2020. [CrossRef]

56. Farooq, F.; Amin, M.N.; Khan, K.; Sadiq, M.R.; Javed, M.F.F.; Aslam, F.; Alyousef, R. A comparative study of random forest and genetic engineering programming for the prediction of compressive strength of High Strength Concrete (HSC). Appl. Sci. 2020, 10, 7330. [CrossRef]

57. Asteris, P.G.; Kolovos, K. Self-compacting concrete strength prediction using surrogate models. Neural Comput. Appl. 2019, 31, 409-424. [CrossRef]

58. Selvaraj, S.; Sivaraman, S. Prediction model for optimized self-compacting concrete with fly ash using response surface method based on fuzzy classification. Neural Comput. Appl. 2019, 31, 1365-1373. [CrossRef]

59. Zhang, J.; Ma, G.; Huang, Y.; Sun, J.; Aslani, F.; Nener, B. Modelling uniaxial compressive strength of lightweight self-compacting concrete using random forest regression. Constr. Build. Mater. 2019, 210, 713-719. [CrossRef]

60. Kaveh, A. M5' and Mars based prediction models for properties of self-compacting concrete containing fly ash. Period. Polytech. Civ. Eng. 2017, 62, 281-294. [CrossRef]

61. Sathyan, D.; Anand, K.B.; Prakash, A.J.; Premjith, B. Modeling the fresh and hardened stage properties of self-compacting concrete using random kitchen sink algorithm. Int. J. Concr. Struct. Mater. 2018, 12, 24. [CrossRef]

62. Vakhshouri, B.; Nejadi, S. Prediction of compressive strength of self-compacting concrete by ANFIS models. Neurocomputing 2018, 280, 13-22. [CrossRef]

63. Douma, O.B.; Boukhatem, B.; Ghrici, M.; Tagnit-Hamou, A. Prediction of properties of self-compacting concrete containing fly ash using artificial neural network. Neural Comput. Appl. 2016, 28, 707-718. [CrossRef] 
64. Abu Yaman, M.; Elaty, M.A.; Taman, M. Predicting the ingredients of self compacting concrete using artificial neural network. Alex. Eng. J. 2017, 56, 523-532. [CrossRef]

65. Farooq, F.; Ahmed, W.; Akbar, A.; Aslam, F.; Alyousef, R. Predictive modeling for sustainable high-performance concrete from industrial wastes: A comparison and optimization of models using ensemble learners. J. Clean. Prod. 2021, 292, 126032. [CrossRef]

66. Bušić, R.; Benšić, M.; Miličević, I.; Strukar, K. Prediction models for the mechanical properties of self-compacting concrete with recycled rubber and silica fume. Materials 2020, 13, 1821. [CrossRef]

67. Javed, M.F.; Farooq, F.; Memon, S.A.; Akbar, A.; Khan, M.A.; Aslam, F.; Alyousef, R.; Alabduljabbar, H.; Rehman, S.K.U. New prediction model for the ultimate axial capacity of concrete-filled steel tubes: An evolutionary approach. Crystals 2020, 10, 741. [CrossRef]

68. Al-Mughanam, T.; Aldhyani, T.; AlSubari, B.; Al-Yaari, M. Modeling of compressive strength of sustainable self-compacting concrete incorporating treated palm oil fuel ash using artificial neural network. Sustainability 2020, 12, 9322. [CrossRef]

69. Nematzadeh, M.; Shahmansouri, A.A.; Fakoor, M. Post-fire compressive strength of recycled PET aggregate concrete reinforced with steel fibers: Optimization and prediction via RSM and GEP. Constr. Build. Mater. 2020, 252, 119057. [CrossRef]

70. Ergün, A.; Kürklü, G.; Serhat, B.M.; Mansour, M.Y. The effect of cement dosage on mechanical properties of concrete exposed to high temperatures. Fire Saf. J. 2013, 55, 160-167. [CrossRef]

71. Cülfik, M.S.; Özturan, T. Mechanical properties of normal and high strength concretes subjected to high temperatures and using image analysis to detect bond deteriorations. Constr. Build. Mater. 2010, 24, 1486-1493. [CrossRef]

72. Behnood, A.; Ziari, H. Effects of silica fume addition and water to cement ratio on the properties of high-strength concrete after exposure to high temperatures. Cem. Concr. Compos. 2008, 30, 106-112. [CrossRef]

73. Bastami, M.; Baghbadrani, M.; Aslani, F. Performance of nano-silica modified high strength concrete at elevated temperatures. Constr. Build. Mater. 2014, 68, 402-408. [CrossRef]

74. Chen, L.; Fang, Q.; Jiang, X.; Ruan, Z.; Hong, J. Combined effects of high temperature and high strain rate on normal weight concrete. Int. J. Impact Eng. 2015, 86, 40-56. [CrossRef]

75. Xiong, Y.; Deng, S.; Wu, D. Experimental study on compressive strength recovery effect of fire-damaged high strength concrete after realkalisation treatment. Procedia Eng. 2016, 135, 476-481. [CrossRef]

76. Mousa, M.I. Effect of elevated temperature on the properties of silica fume and recycled rubber-filled high strength concretes (RHSC). HBRC J. 2017, 13, 1-7. [CrossRef]

77. Fu, Y.F.; Wong, Y.L.; Poon, C.S.; Tang, C.A. Stress-strain behaviour of high-strength concrete at elevated temperatures. Mag. Concr. Res. 2005, 57, 535-544. [CrossRef] 